\title{
High-resolution spatial distribution and associated uncertainties of greenhouse gas emissions from the agricultural sector
}

\author{
Nadiia Charkovska ${ }^{1}$ - Joanna Horabik-Pyzel ${ }^{2} \cdot$ Rostyslav Bun $^{1,3} \cdot$ Olha Danylo $^{4}$. \\ Zbigniew Nahorski $^{2,5}$ (D) Matthias Jonas $^{4} \cdot$ Xu Xiangyang $^{6}$
}

\begin{abstract}
Agricultural activity plays a significant role in the atmospheric carbon balance as a source and sink of greenhouse gases (GHGs) and has high mitigation potential. The agricultural emissions display evident geographical differences in the regional, national, and even local levels, not only due to spatially differentiated activity, but also due to very geographically different emission coefficients. Thus, spatially resolved inventories are important for obtaining better estimates of emission content and design of GHG mitigation processes to adapt to global carbon rise in the atmosphere. This study develops a geoinformation approach to a highresolution spatial inventory of GHG emissions from the agricultural sector, following the categories of the United Nations Intergovernmental Panel on Climate Change guidelines. Using the Corine Land Cover data, a digital map of emission sources is built, with elementary areal objects that are split up by administrative boundaries. Various procedures are developed for disaggregation of available emission activity data down to a level of elementary emission objects, conditional on covariate information, such as land use, observable in the elementary object scale. Among them, a statistical scaling method suitable for spatially correlated areal emission sources is applied. As an example of implementation of this approach, the spatial distribution of methane $\left(\mathrm{CH}_{4}\right)$ and Nitrogen Oxide $\left(\mathrm{N}_{2} \mathrm{O}\right)$ emissions was obtained for areal
\end{abstract}

Electronic supplementary material The online version of this article (https://doi.org/10.1007/s11027-0179779-3) contains supplementary material, which is available to authorized users.

\section{Zbigniew Nahorski}

Zbigniew.Nahorski@ibspan.waw.pl

Lviv Polytechnic National University, Lviv, Ukraine

2 Systems Research Institute of the Polish Academy of Sciences, Warsaw, Poland

3 University of Dąbrowa Górnicza, Dąbrowa Górnicza, Poland

4 International Institute for Applied Systems Analysis, Laxenburg, Austria

5 Warsaw School of Information Technology, Warsaw, Poland

6 China University of Mining and Technology, Beijing, China 
emission sources in the agriculture sector in Poland with a spatial resolution of $100 \mathrm{~m}$. We calculated the specific total emissions for different types of animal and manure systems as well as the total emissions in $\mathrm{CO}_{2}$-equivalent. We demonstrated that the emission sources are located highly nonuniformly and the emissions from them vary substantially, so that average data may provide insufficient approximation. In our case, over $11 \%$ smaller emission was estimated using spatial approach as compared with the national inventory report where average data were used. In addition, we quantified uncertainties associated with the developed spatial inventory and analysed the dominant components in total emission uncertainties in the agriculture sector. We used the activity data from the lowest possible (municipal) level. The depth of disaggregation of these data to the level of arable lands is minimal, and hence, the relative uncertainty of spatial inventory is smaller when comparing with traditional gridded emissions. The proposed technique allows us to discuss factors driving the geographical distribution of GHG emissions for different categories of the agricultural sector. This may be particularly useful in high-resolution modelling of GHG dispersion in the atmosphere.

Keywords GHG emissions · Spatial inventory · Agriculture sector · Uncertainty · Geoinformation system $\cdot$ High-resolution (big) data

\section{Introduction}

During the last century, the environment has experienced significant global climate change (IPCC 2014). By now, research has affirmed that to a large extent, climate change is the result of anthropogenic activities (Cook et al. 2016). According to the latest assessment report of the United Nations Intergovernmental Panel on Climate Change (IPCC), human activities have to be attributed to be the main reason of this change, with above 95\% degree of confidence (IPCC 2013). Global climate change has seriously impacted the economy of a number of countries and, consequently, humanity as such. For example, higher frequencies of droughts and floods have been observed universally, causing significant reductions in agricultural production (Lesk et al. 2016). In turn, agricultural production causes considerable amounts of greenhouse gases (GHGs) and mainly carbon dioxide $\left(\mathrm{CO}_{2}\right)$, methane $\left(\mathrm{CH}_{4}\right)$, and nitrous oxide $\left(\mathrm{N}_{2} \mathrm{O}\right)$ (IPCC 2006). Therefore, achieving the $2{ }^{\circ} \mathrm{C}$ limit target will not be possible without a significant reduction of GHG emissions from the agriculture sector (Wollenberg et al. 2016).

The share of the agricultural sector in global total GHG emissions is about 13\% (in 2012). Agriculture is responsible for $53 \%$ of global non- $\mathrm{CO}_{2}$ emissions, and therefore, it has essential mitigation potential and costs of reducing GHG emissions (Beach et al. 2016; Gerber et al. 2016; Johnson et al. 2007; Smith et al. 2008). Due to meteorological conditions, development level and many other factors, the share of agricultural emissions is not the same around the world. This can be illustrated by the example of the European Union (EU) member states where Ireland has the largest share of the agricultural sector in its total GHG emissions $(30.77 \%)$, while the smallest is in Malta $(3.23 \%)$, with the average share for EU equal $10.35 \%$ (in 2012) (AGHGS 2017). At the same time, in the absolute terms, the largest emissions in the agriculture sector are in France (89.3 million tonnes of $\mathrm{CO}_{2}$-equivalent), Germany (69.5), UK (51.8), and Spain (37.7). Poland with 36.7 million tonnes of $\mathrm{CO}_{2}{ }^{-}$ equivalent is in the fifth place.

If we consider non-fossil fuel GHG emissions, the main categories of GHG emissions in the agriculture are enteric fermentation, manure management, and agricultural soil (IPCC 2006). 
The livestock farming plays an important ecological, economic, and social role in various parts of the world (Havlík et al. 2015). According to IPCC (2006), the emissions of GHG from the animal sector are mainly a result of enteric fermentation (dairy and nondairy cattle, sheep, goats, horses, and pigs) where methane emissions are produced in large quantities during the digestive process of ruminants, and decomposition, collection, storage, and use of animal manure in various storage systems (manure reservoir in solid and liquid forms, separately). So far, science has not evaluated the long-term trend of GHG emissions from the animal sector separately for developed and developing countries (Caro et al. 2014). Apart from livestock, cultivated lands (arable lands) manured by various kinds of fertilisers can be regarded as areal sources of emissions, with leaching and runoff of nitrous oxide and other nitrogen compounds (Butterbach-Bahl et al. 2013).

Emissions from agricultural activities have been a subject of many studies; see, e.g. a review by Snyder et al. (2009). Some types of emissions have attracted higher attention from the scientific community due to their more complex nature (Ogle et al. 2013). For example, Herrero et al. (2015) published a review of the problems resulting from the livestock production. The publications emphasise the large spatial variations of emissions, due to, e.g. different soil types, different climatic parameters and water conditions, or different fertilisation strategies and manure management practices. Some publications are devoted to regional or national studies. For example, methane emissions from agricultural activities in China have been analysed by $\mathrm{Fu}$ and $\mathrm{Yu}$ (2010); measurements of $\mathrm{N}_{2} \mathrm{O}$ emissions in Europe from several grassland sites have been reported by Soussana et al. (2007); $\mathrm{N}_{2} \mathrm{O}$ emissions from arable land, calculated by simulations using the DNDC-Europe model, have been evaluated by Leip et al. (2011); emissions from the livestock sector in the EU have been calculated using the CAPRI model by Weiss and Leip (2012). As far as gridded emissions are concerned, Yao et al. (2006) estimated methane emissions from rice (Oryza) paddies in China, with a spatial resolution of $10 \mathrm{~km} \times 10 \mathrm{~km}$; EDGAR (2017) published gridded emissions from enteric fermentation, manure management, and agricultural soil with a spatial resolution of $0.1^{\circ} \times 0.1^{\circ}$ latitude and longitude (about $11 \times 11 \mathrm{~km}$ for the equator).

In order to plan the strategic development of individual regions and evaluate their mitigation potential, it is more adequate to build spatial emission inventories on small areas of the territory; see, e.g. Trombetti et al. (2017). This is one of main reasons why estimation of emissions with high spatial resolution is a subject of many studies, but a vast majority of them dealt with emissions from fossil fuel consumption; see the list of references in Bun et al. (2018). At the same time, well-focussed and more intensive emission mitigations, when applied widespread, will have in effect a positive impact on achieving the global target limit of GHG concentration in the atmosphere.

Although all of the above mentioned studies related to agriculture have adopted a spatial or spatiotemporal approach, this is usually confined to larger territories. Therefore, a special interest exists for mapping GHG emissions in the main categories of the agriculture sector with resolution that matches spatial differentiability of agricultural activity.

The IPCC has developed a universal methodology of GHG inventory in different categories of anthropogenic activity, including agriculture (IPCC 2006), that standardises procedures of preparing national inventory reports of GHG emissions at the country level. However, these methods are ineffective in the evaluation of emissions at the local level, because they do not take into account the specificity of emission processes and irregularity of territorial distribution of the emission sources.

Relevant information about high-resolution activity data needs to be acquired from national/regional totals. A common approach of the spatial allocation of data into smaller 
spatial units (such as districts, municipalities, and finally grid cells) is their disaggregation in proportion to some related indicators (proxies) that are available in a finer scale. Kim and Dall'erba (2014) found a high spatial correlation of fossil fuel $\mathrm{CO}_{2}$ emissions from crop production in the US; this might also apply to other GHG emissions in the agricultural sector. So, in advanced analysis, it is worth considering the correlation between some proxy data, for example, using tools of geostatistical modelling such as universal kriging (Young et al. 2016) or autoregressive methods, and among them conditional (Horabik and Nahorski 2010) or spatial (Kim and Dall'erba 2014) autoregression models.

The IPCC (2001) recommends the uncertainty analysis of any GHG inventory due to its possible high values. This analysis can be mostly used also for GHG spatial inventory (Bun et al. 2007). Following the IPCC (2001) recommendations, uncertainties of the compiled emissions have been assessed in some papers. For example, Zhang et al. (2014) and Zhu et al. (2016) performed uncertainty calculations for rice paddies and livestock, respectively, applying the Monte Carlo method. Berdanier and Conant (2012) used data from 32 national emission inventories and a model for emission of $\mathrm{N}_{2} \mathrm{O}$ from soils to estimate regional model parameter distributions using the Bayesian Markov Chain Monte Carlo method to compute emission distributions.

The main objective of this study is to develop an approach for high-resolution spatial inventory of GHG emissions in the agriculture sector using statistical data and land cover map. This approach is implemented in the agricultural sector of Poland, to manifest its ability of achieving the goal. Using the created digital maps of emission sources and mathematical models, we carried out an inventory of emissions and obtained sets of geospatial GHG emission data for each elementary areal object due to enteric fermentation, manure management, agricultural soils, etc., according to the agricultural sector structure in the IPCC guidelines. The maximum resolution of this spatial inventory is determined by the resolution of the used digital maps of land use and, in our case, does not exceed $100 \mathrm{~m}$. Uncertainty of calculated emissions is estimated and their mitigation potential is evaluated.

For disaggregation of activity data published for higher level administrative units (districts) to the municipality level, we applied an original conditional autocorrelation (CAR) method that is based on Horabik and Nahorski (2015) approach and takes into account spatial correlation of the data, thereby enabling us to obtain more accurate disaggregation.

The approach to spatial inventory presented in this study can be used for many other countries. It particularly fits to countries with nonhomogeneous agricultural structure, which is the case of Poland.

\section{Input data}

\subsection{Study area description}

Poland, one of EU countries, covers an area of $312 \mathrm{~km}^{2}$ with a population of over 38 million people. It is divided administratively to 16 provinces (voivodeships), 380 districts (powiats), and 2478 municipalities (gminas); the latter include urban (302), urban-rural (621), and rural (1555) municipalities (PBI 2017). Two latter types are considered in the study.

Poland plays a significant role in the European agriculture, as it has a high potential for intensification and technological advancement as compared to western EU countries. At the 
same time, it is much more similar to many developing countries within and out of EU. That is why it is an interesting case for investigations.

Polish agrotechnical practices diverse a lot spatially due to different traditions in territories annexed to three neighbouring countries during partition of the Polish-Lithuanian Commonwealth at the end of the eighteenth century that lasted for 123 years. This diverse still exists despite a century from restoration of Polish independence after the first World War.

Big recent changes in the Polish agriculture have occurred since the start of the economic transformation to the market economy in 1989 and later when Poland became a member state of the European Union in 2004. The main restructuring was connected with privatisation of the arable land (95.6\% according to the 2010 census), its concentration in larger farms and commercialisation (CSOP 2010). On the other hand, quick urbanisation caused partitions of many arable lands and their use for housing and recreation. Nevertheless, traditional small farms still prevail. In 2010, the average farm acreage was 6.85 ha (CSOP 2010).

Despite recent development, there is still big potential for further intensification of the Polish agriculture. For this, however, strategic decisions are needed. Territory of Poland is located in the temperate climatic zone with strong influence of polar and tropical air masses from the north-south direction and maritime and continental from the west-east one. Polish agriculture is partly temperature- and partly water-restricted. Climate change models predict increase of vegetation period length but at the same time drier condition in most of the Polish territory and in a consequence decrease of crop yields (Szwed et al. 2010). So, thorough changes in agrotechnical practices will be needed. Emissions of GHG can be used in them as one of the considered criteria.

\subsection{Input datasets}

In the spatial analysis of emission processes in the animal subsector in Poland, we took into account the IPCC (2006) categories 4.A 'Enteric Fermentation' and 4.B 'Decomposition, Collection, Storage, and Use of Animal Manure'. In the plant growing subsector, we considered the categories 4.D ‘Agricultural Soils' and 4.F 'Field Burning of Agricultural Residues'. According to the basic IPCC (2006) approach, the GHG emissions depend on activity data and emission factors, which were provided for the study area. We also used high-resolution maps of analysed territory and implemented procedures for disaggregation of the data to smaller plots with a homogeneous agricultural activity.

Statistical data on animal stocks were taken from Local Data Bank (BDL 2017), which contains data on number of heads for dairy cattle, nondairy cattle, sheep, goats, horses, swines, and poultry, acquired from Agricultural Census 2010 (CSOP 2010). These data are given separately for farms and households. The data were gathered for the lowest administrative level of municipalities. The data which were available only for the districts, like horses and goats, were disaggregated to the municipality level using our own developed method described in the next section.

The following input data were used for the considered GHG categories:

- Category 'Enteric Fermentation': the map of rural settlements; number of dairy cattle, nondairy cattle, sheep, swine, poultry, goat, and horse heads at municipal level (BDL 2017); emission coefficients (NIR 2012; IPCC 2006); and areas of rural settlements as proxy data; 
- Category 'Manure Management': the maps of rural settlements and arable lands (EEA 2006); number of animals at municipal level (BDL 2017); data on nitrogen excretion per animal waste management system and emission coefficients (NIR 2012; IPCC 2006); and areas of rural settlements and arable lands as proxy data;

- Category 'Agricultural Soils': the map of arable lands (EEA 2006); data on nitrogen input from agricultural processes, area of cultivated organic soil at national and provincial levels (CSOP 2010; NIR 2012); emission coefficients (IPCC 2006); and areas of arable lands as proxy data;

- Category 'Field Burning of Agricultural Residues': the map of arable lands (EEA 2006); activity data according to IPCC (2006) at national and provincial levels (CSOP 2010; NIR 2012); emission coefficients (IPCC 2006).

From Corine Land Cover 2006 map (EEA 2006), we used the classes 2.1 'Arable Land', 2.3 'Pastures', and 2.4 'Heterogeneous Agricultural Areas'. This raster map with a resolution of $100 \mathrm{~m}$ was converted to a vector one. The accuracy of this product is $87.82 \%$ (Büttner et al. 2012).

\section{Research methods}

The main idea of our approach consists in developing a methodology to compile the spatial inventory of GHG emissions directly on the level of emission sources. The gridded emissions (Fig. 1) are calculated only at the final stage, for presentation. Therefore, our main attempt was in proper definitions of possibly homogenous emission sources. Agricultural fields/pastures are examples of such area emission sources. In the animal subsector (in the IPCC categories 'Enteric Fermentation' and 'Decomposition, Collection, Storage, and Use of Animal Manure'), there is no practical possibility to monitor emissions from individual animals, so the total emissions from all animals of one species within each rural locality in general were treated as one emission source. In the proposed mathematical models, it was also taken into account that statistical data on livestock and poultry are published separately for the agricultural enterprises and the households in municipalities.

We analyse the sources of spatial emissions for all categories of the agriculture sector covered by the IPCC (2006) guidelines, treating emission sources as areal (diffused) objects. The digital maps of these sources are built using Corine Land Cover vector map (EEA 2006) as polygons, without using any regular grid, contrary to usual practice. Such elementary areal objects (polygons) are split up by administrative boundaries of regions (voivodeships in Poland), districts (powiats), and municipalities (gminas). Subsequently, we create algorithms for calculating GHG emissions from these objects using the activity data and the emission coefficients.

Pre-processing input data includes the following:

- Converting land cover map to a vector format, in order to have a possibility to keep information on administrative assignment of each settlement, agricultural land, etc. without loss of accuracy;

- Disaggregation of the statistical/activity data on livestock and poultry to the municipality level (only for species given in BDL (2017) solely on the district level, e.g. horses and goats); 


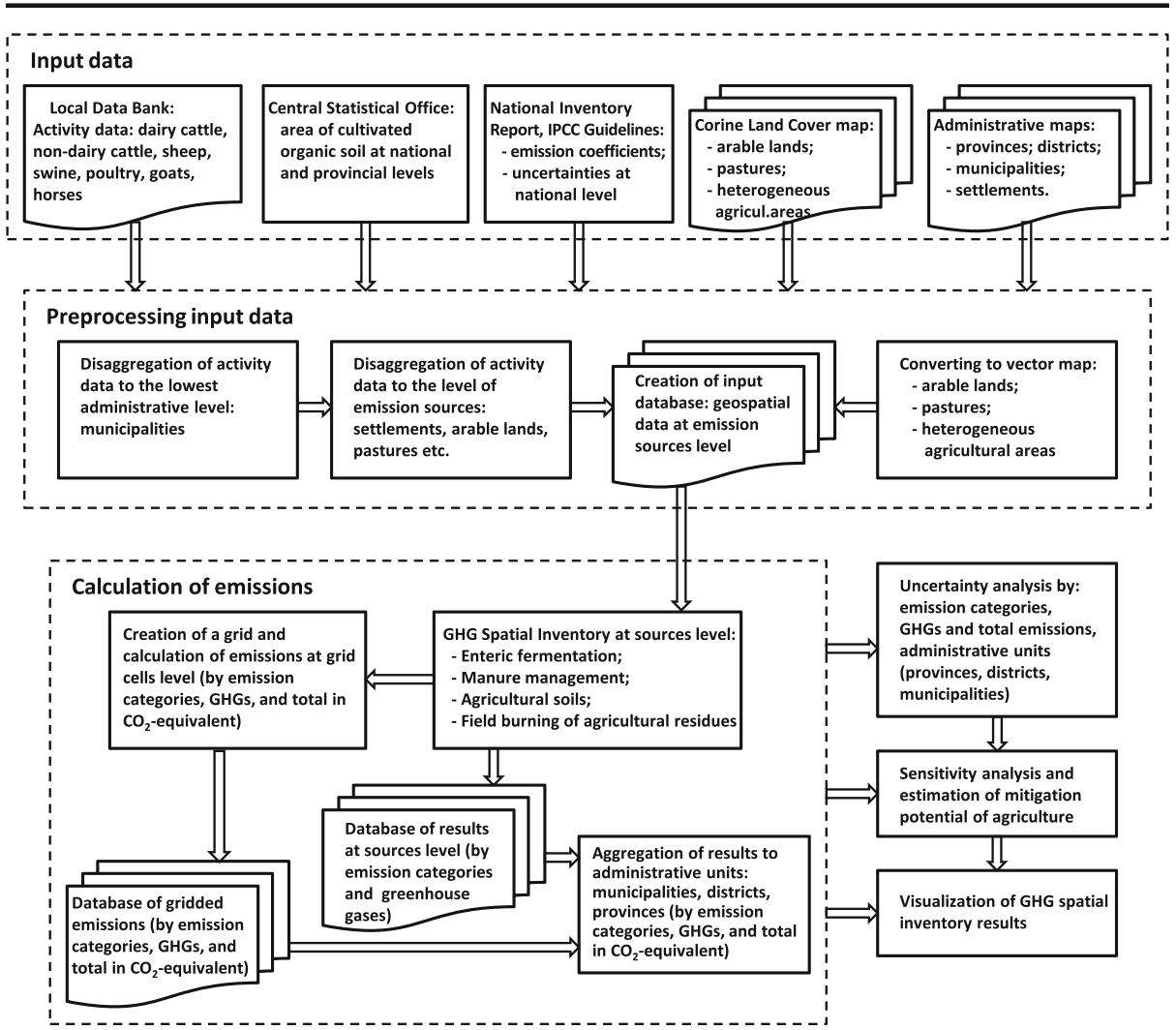

Fig. 1 Flow chart of geoinformation approach to high-resolution spatial inventory of GHG in the agriculture sector

- Disaggregation of statistical data from municipalities to emission source level (arable lands, pastures, and rural settlements).

For the activity data assessment, we developed algorithms for disaggregation of available statistical data to the lowest possible level of elementary areas. In particular, for spatial allocation of livestock census data from district to municipality level, we present a novel approach based on the conditional autoregressive (CAR) structure, following the basic model proposed by Horabik and Nahorski (2014). Regarding an assumption on residual covariance, it allows for allocating GHG activity data to finer spatial scales, conditional on covariate information, such as land use, observable in a coarse grid (see Appendix). We demonstrate the usefulness of the proposed technique for GHG spatial inventory in the agricultural sector, using an example of allocation of livestock data (cattle, pigs, horses, poultry, etc.) from the district to the municipality level in Poland, based on the agricultural census 2010 (BDL 2017). In particular, for horses, the data were available also in municipalities, and this fact enabled us to validate the proposed disaggregation model. Only rural and urban-rural municipalities (according to official administrative classification) were considered here.

As explanatory (proxy) variables, we used the average population density within municipalities and land use information. For the latter, the Corine Land Cover map 
(EEA 2006) was employed. For each municipality, we calculated the area of the agricultural classes, which may be related to livestock farming. Three Corine classes were considered (the class numbers are given in brackets): arable land (2.1), pastures (2.3), and heterogeneous agricultural areas (2.4). These proxy variables were statistically tested in the model for their significance and insignificant ones were dropped. The estimation results (parameters with their standard errors) are presented in the Appendix (Table 3). The models with and without a spatial component, denoted CAR and LM (linear model), are compared. We also added the results obtained for allocation proportional to population in municipalities, called there naïve $(\mathrm{NV})$ which is a straightforward and commonly used approach.

Taking into account the residuals, the mean squared error, and the sample correlation coefficient between the predicted and observed values, we demonstrated that the spatial CAR structure considerably improves the results obtained by using the LM model; see Table 4 in the Appendix. The NV approach provides reasonable results, but the CAR model outperforms it in terms of all the reported criteria. The decrease of the mean squared error ranged from 3374.4 for NV to 3069.4 for CAR, with an improvement of 9\%. Figure 2 presents the maps with data on number of horses in municipalities (a) as well as the values predicted with the model CAR (b). For better visibility, Fig. 2 shows the maps for a single province (Kuyavian-Pomeranian), although the disaggregation was made for the whole territory of Poland. It should be noted that the obtained improvement depends on the spatial correlation strength of the activity data. In particular, with weak correlations, application of the CAR technique may not improve disaggregation.

For final disaggregation of activity data from municipality level to the level of emission sources, it was assumed that the animals in the households in municipality settlements are distributed proportionally to the rural population (the rural population map was created using corresponding polygons of Corine Land Cover vector map (EEA 2006) after the removal of polygons of cities; accordingly, the rural population of the municipalities was disaggregated between rural settlements in proportion to their area). The ratio of the population in each analysed areal emission source (settlement in this case) and the population in municipality was used as a proxy for disaggregation of the

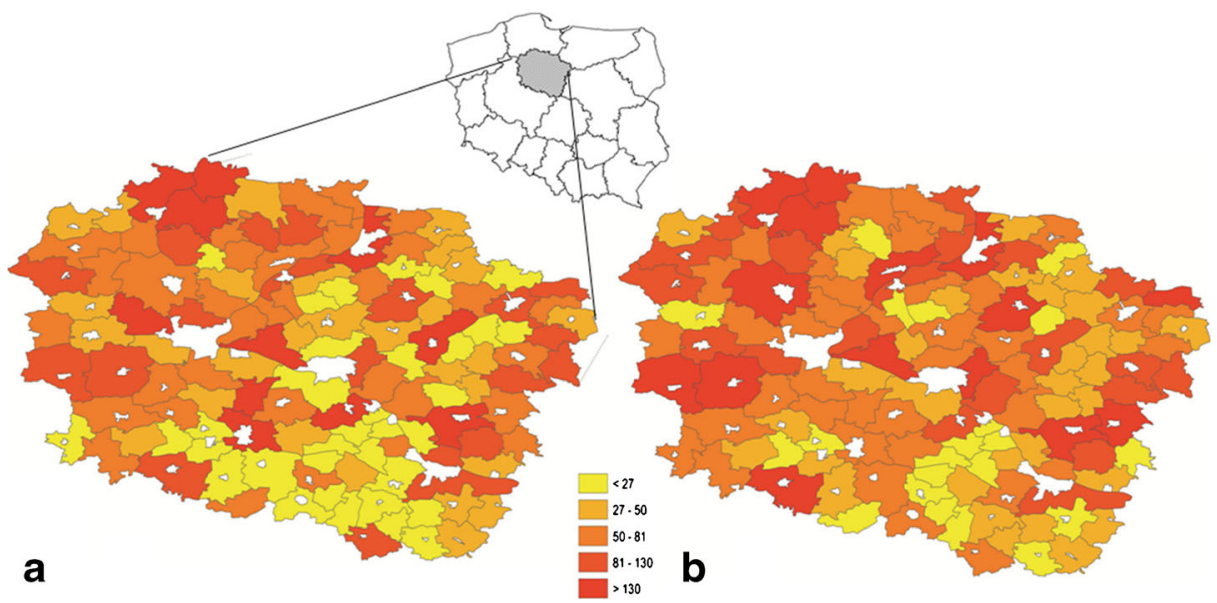

Fig. 2 Original data on number of horses in municipalities of Kuyavian-Pomeranian province (a) as well as predicted values for the model CAR (b) 
number of animal livestock in the households within the municipality to the level of emission sources.

The statistical data on livestock and poultry within agricultural enterprises were therefore disaggregated to the level of emission sources (arable land, grassland, etc. in this case) in proportion to the area of these lands belonging to the farm. The ratio of the area of each agricultural land and the sum of such areas of the lands in the municipality was used as a proxy for disaggregation of the number of animal livestock in the farms within the municipality to the level of emission sources.

The total annual emissions of methane from enteric fermentation of animals in the households and agricultural enterprises within elementary area $\delta_{n}$ were calculated using the model:

$$
E_{\text {EntFerm }}^{\mathrm{CH}_{4}}\left(\delta_{n}\right)=\sum_{t=1}^{T}\left[A_{t}^{\text {ind }}\left(R_{m}\right) \times V_{t}\left(\delta_{n}\right)+A_{t}^{a g r}\left(R_{m}\right) \times S_{t}\left(\delta_{n}\right)\right] \times K_{t}^{\mathrm{CH}_{4}}\left(\delta_{n}\right), \quad n=\overline{1, N},
$$

where $A_{t}^{\text {ind }}\left(R_{3, n_{3}}\right)$ and $A_{t}^{a g r}\left(R_{3, n_{3}}\right)$ are the statistical data on the number of the $t$-th animal species (dairy cattle, nondairy cattle, sheep, goats, horses, pigs, poultry) in individual rural households, denoted by ind in the superscript, and agricultural enterprises (agr in the superscript) for the chosen year in municipality $R_{m}$, which contains the elementary area $\delta_{n} ; V_{t}\left(\delta_{n}\right)$ and $S_{t}\left(\delta_{n}\right)$ are the mentioned above ratios for the population and agricultural land in an analysed elementary area $\delta_{n}$, used for disaggregation of the municipality level livestock data on the $t$-th animal species in the households and agricultural farms from municipality $R_{m}$ to the level of the elementary area; $K_{t}^{C_{4}}\left(\delta_{n}\right)$ is the coefficient of methane emission from enteric fermentation for the $t$-th animal species in the $n$-th elementary area (depending on the climate zone in which this area is located); EntFerm represents the emissions from enteric fermentation.

To calculate emissions from agricultural soils, we considered the arable lands treated as areal emission sources. In particular, nitrous oxide emissions from agricultural soils occur when the microbial processes of nitrification and denitrification in the soils take place. They include direct soil emissions, indirect soil emissions, and emissions induced by grazing animals. When modelling the emission processes in the soil subsector (in the category 'Direct Soil Emissions'), we computed the total nitrogen inputs for (1) synthetic fertiliser applied, converted to the amount of nitrogen used per hectare of the planted crop; (2) animal waste applied to soils as fertiliser (using as statistical data the number of each animal type and the annual per head amount of nitrogen produced by an animal type); (3) nitrogen fixation by $\mathrm{N}$-fixing crops (using statistical data on sown areas of different $\mathrm{N}$-fixing crops, mainly pulses); and (4) nitrogen content of crop residues. The total amount of nitrogen input was corrected to account for the fraction of nitrogen that volatilises as $\mathrm{NO}_{\mathrm{x}}$ and $\mathrm{NH}_{3}$. Emission estimates were obtained by multiplying the corrected nitrogen input with the emission factor.

We treated grid cells as polygons in the vector map to combine the calculated methane and nitrous oxide emissions from diverse sources in animal and soil subsectors to estimate the total emissions in the agriculture sector. Because vector maps were used, it was possible to divide the grid cells into smaller areas when they belonged to more than one municipality. The grid size may be arbitrary. It depends on the task solved and it is of no importance at this stage, as our spatial inventory has been done at the level of emission sources. However, the final grid size cannot be smaller than $100 \mathrm{~m}$, because applied land cover map was of this resolution. 
Nevertheless, the emission results that are coded in vector maps can be easily aggregated to the levels of municipalities, districts, and provinces without loss of accuracy.

\section{Results}

\subsection{The spatially explicit GHG inventories for Poland}

Implementing the above mathematical models and disaggregation algorithms, we obtained spatial estimates of GHG emissions for each IPCC source category in the agricultural sector in Poland, i.e. '4A. Enteric Fermentation', ‘4B. Manure Management', ‘4D. Agricultural Soils', and '4F. Burning of Agricultural Residues'. The inventory was calculated at the level of polygons as areal emission sources (rural settlements, arable lands, and pastures). Full geospatial data for all emission categories at the level of the areal emission sources as well as at that of the grid $(2 \times 2 \mathrm{~km})$ are available in Supplementary Materials.

Livestock The largest emissions in the agricultural sector are from enteric fermentation by farm and household animals, such as dairy and nondairy cattle (see Figs. 3 and 4). The total emissions of $\mathrm{CH}_{4}$ from enteric fermentation of all species in 2010 amount to $434.7 \mathrm{Gg}$, representing $75 \%$ of the total emissions in the animal sector. The remaining $25 \%(145.0 \mathrm{Gg})$ are caused by decomposition of animal manure. The highest methane emissions from enteric fermentation are found in the Masovian, Greater Poland, and Podlaskie provinces, while the lowest are observed in the Lubusz province (Table 1). The highest $\mathrm{CH}_{4}$ emissions from decomposing manure (IPCC categories 4B1-4B9) are in Greater Poland, Masovian, and Kuyavian-Pomeranian provinces.

The total national emissions of nitrous oxide from the storage and use of animal waste (4B11-4B12 categories) amount to $12.3 \mathrm{Gg}\left(21.2 \%\right.$ of total $\mathrm{N}_{2} \mathrm{O}$ emission in the agricultural sector): $0.1 \mathrm{Gg}$ for the liquid waste and $12.2 \mathrm{Gg}$ for the solid waste, respectively (Table 1).

Total specific $\mathrm{GHG} \mathrm{CO}_{2}$-equivalent emissions from the animal sector (4A and $4 \mathrm{~B}$ subsectors) are illustrated in Fig. 5. Our results show that the distribution of GHG emissions is highly uneven. The greatest emissions are in the rural municipality Wierzchowo (id 3203052) in West Pomeranian province. In this municipality, livestock numbers in 2010 are as follows: pigs 829,597 , total cattle 595 , dairy cattle (cows) 229 , goats 14 , sheep 22 , horses 23 , poultry 5369 . The municipality of Wierzchowo covers an area of $230.2 \mathrm{~km}^{2}$; total annual emissions in the municipality in 2010 amount to $183,408.6 \mathrm{Mg}_{\mathrm{CO} 2 \text {-eq }}$. Therefore, the average annual emission per unit of area is $796.7 \mathrm{Mg}_{\mathrm{CO} 2 \text {-eq }} / \mathrm{km}^{2} /$ year. The municipality Wierzchowo consists of 79 grid cells of the area $2 \mathrm{~km} \times 2 \mathrm{~km}$. In 27 of them, see Fig. 5, the highest specific emissions are between 700 and $2756 \mathrm{Mg}_{\mathrm{CO} 2 \text {-eq }} / \mathrm{km}^{2} /$ year. This exemplifies a significant local variety of emission magnitude. In the remaining 52 cells, there are mainly forests and no agricultural activity. The total $183,408.6 \mathrm{Mg}_{\mathrm{CO} 2 \text {-eq }}$ emission consists of the following:

1) $\mathrm{CH}_{4}$ emission from enteric fermentation of all species owned by the rural population, which is $41.92 \mathrm{Mg}_{\mathrm{CH} 4}\left(1048.0 \mathrm{Mg}_{\mathrm{CO} 2 \text {-eq }}\right)$;

2) $\mathrm{CH}_{4}$ emission from enteric fermentation of all species owned by agricultural households, which is $1000.3 \mathrm{Mg}_{\mathrm{CH} 4}\left(25,008.4 \mathrm{Mg}_{\mathrm{CO} 2 \text {-eq }}\right)$;

3) $\mathrm{CH}_{4}$ emission from decomposition of manure of all species, which is $3995.3 \mathrm{Mg}_{\mathrm{CH} 4}$ $\left(99,882.1 \mathrm{Mg}_{\mathrm{CO} 2-\mathrm{eq}}\right)$; 


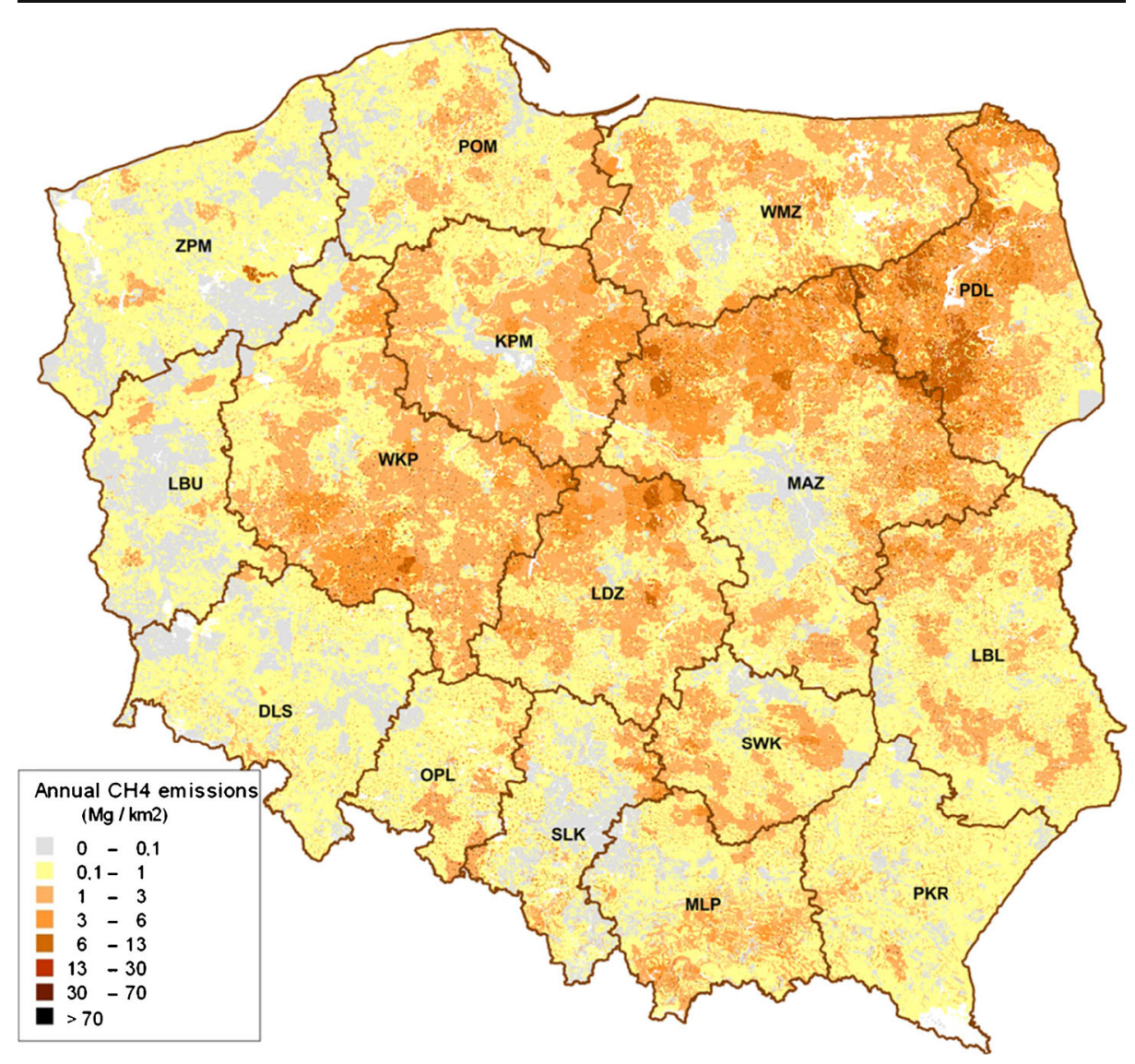

Fig. 3 Spatial distribution of annual emissions of methane from enteric fermentation of agricultural animals in Poland $\left(\mathrm{Mg} / \mathrm{km}^{2}, 2010\right)$

4) $\mathrm{N}_{2} \mathrm{O}$ emission from collection, storage, and use of liquid waste, which is $3.29 \mathrm{Mg}_{\mathrm{N} 2 \mathrm{O}}$ $\left(980.1 \mathrm{Mg}_{\mathrm{CO} 2-\mathrm{eq}}\right)$;

5) $\mathrm{N}_{2} \mathrm{O}$ emissions from collection, storage, and use of solid waste, which is $189.56 \mathrm{Mg}_{\mathrm{N} 2 \mathrm{O}}$ $\left(56,490.0 \mathrm{Mg}_{\mathrm{CO} 2-\mathrm{eq}}\right)$.

Cropland The shares of $\mathrm{N}_{2} \mathrm{O}$ emissions in the agricultural soil categories are 73,25 , and $2 \%$ for direct emissions (4D1 category), indirect emissions (4D2), and grazing livestock (4D3), respectively. Direct soil emissions are due to synthetic fertiliser usage (54\% of total $\mathrm{N}_{2} \mathrm{O}$ emission in 4D1 category), animal waste application (34\%), cultivation of $\mathrm{N}$-fixing crops (pulses) (1\%), cultivation of other crops (10\%), and application of sewage sludge (1\%). As an example of the most important category, the $\mathrm{N}_{2} \mathrm{O}$ emissions from category '4D1. Direct Soil Emissions' at the level of arable lands are presented in Fig. 6. Geospatial results for emissions in other categories are available in Supplementary Materials. 


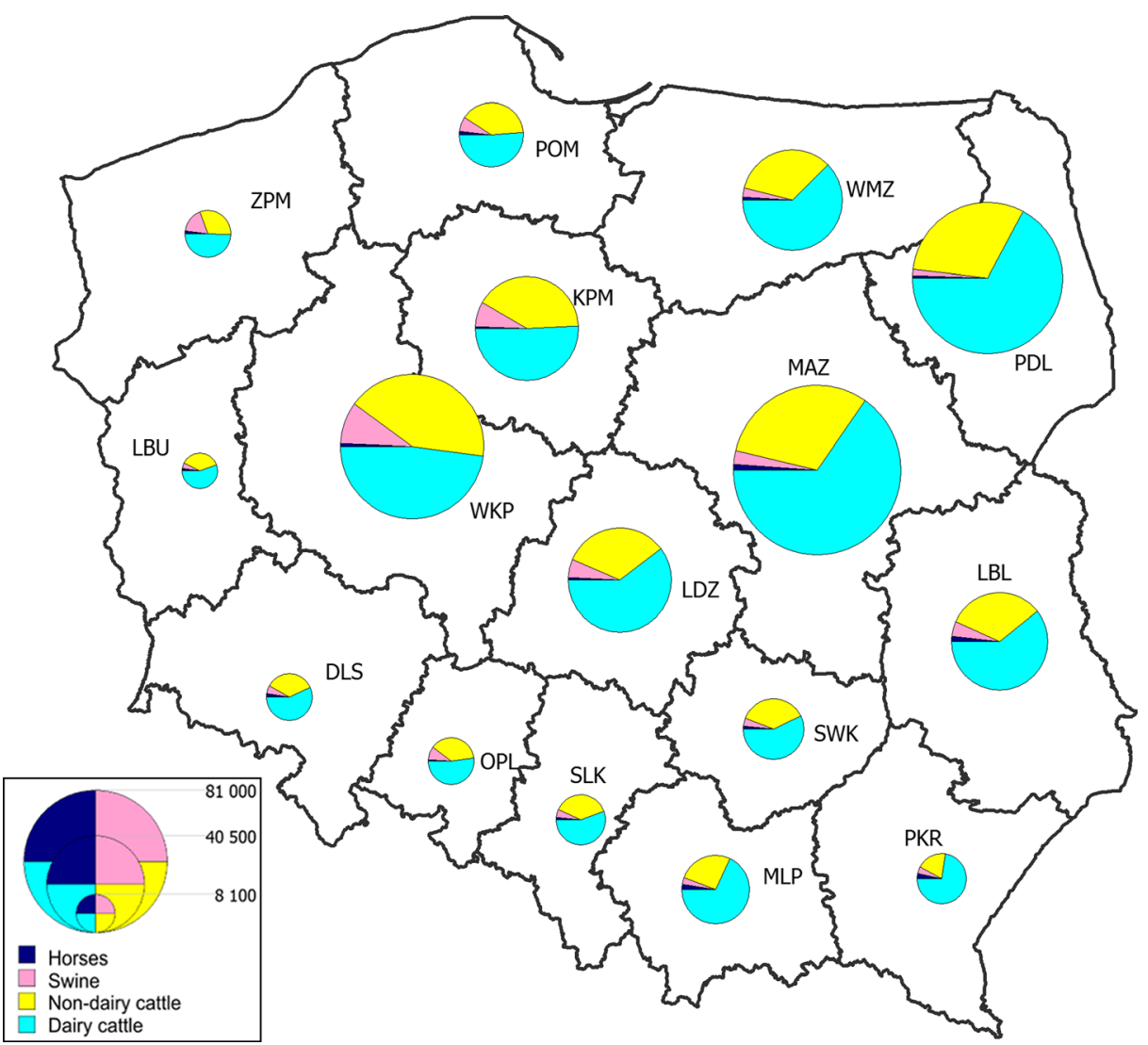

Fig. 4 Annual emissions of methane from enteric fermentation of agricultural animals in the provinces in Poland ( $\mathrm{Mg}, 2010)$. The size of the circles is proportional to emissions, see the scale in the legend. The colours show the share of emissions of the marked species

The share of $\mathrm{N}_{2} \mathrm{O}$ emissions from the IPCC category '4F. Burning Residues of Crops in the Fields' in the total emissions from the agricultural sector is relatively small, $0.001 \%$, that is $0.6 \mathrm{Gg}_{\mathrm{CO} 2 \text {-eq. }}$ It completes the structure of the emission in this sector (Table 1).

Total emissions To calculate specific total $\mathrm{CH}_{4}$ and $\mathrm{N}_{2} \mathrm{O}$ emissions in categories, for different types of animal and manure systems, as well as to easily calculate total emissions in $\mathrm{CO}_{2}$-equivalent for different territories, the results are aggregated in a regular grid of $2 \mathrm{~km} \times$ $2 \mathrm{~km}$, as described in detail in Bun et al. (2018). Subsequently, the results were aggregated to the larger areas, for example, the provinces, when needed.

The specific total $\mathrm{N}_{2} \mathrm{O}$ emissions in the agricultural sector in Poland are presented in Fig. 7 in the regular grid of $2 \mathrm{~km} \times 2 \mathrm{~km}$. Total emissions of nitrous oxide in this sector amount to $57.84 \mathrm{Gg}$. The agricultural soils are the main sources of $\mathrm{N}_{2} \mathrm{O}$ emissions, with a share of $78.76 \%$ or $45.56 \mathrm{Gg}_{\mathrm{N} 2 \mathrm{O}}$. The highest emissions of $\mathrm{N}_{2} \mathrm{O}$ from agricultural soils are found in the Masovian, Greater Poland, and Kuyavian-Pomeranian provinces, and the lowest emissions in the Świętokrzyskie province.

Total GHG emissions in the Polish agricultural sector in the $2 \mathrm{~km} \times 2 \mathrm{~km}$ grid are presented in Fig. 8. In 2010, the major emissions from agricultural activities occur in the Masovian 
Table 1 Annual GHG emissions in the agriculture sector in Poland at the level of provinces (2010)

\begin{tabular}{|c|c|c|c|c|c|c|c|}
\hline \multirow[t]{2}{*}{ Province } & \multirow{2}{*}{$\begin{array}{l}\text { Enteric } \\
\text { fermentation } \\
\mathrm{CH}_{4}(\mathrm{Gg})\end{array}$} & \multicolumn{2}{|c|}{$\begin{array}{l}\text { Manure } \\
\text { management }\end{array}$} & \multirow{2}{*}{$\begin{array}{l}\text { Agricultural } \\
\text { soils } \\
\mathrm{N}_{2} \mathrm{O}(\mathrm{Gg})\end{array}$} & \multicolumn{2}{|c|}{$\begin{array}{l}\text { Burning of } \\
\text { agricultural } \\
\text { residues }\end{array}$} & \multirow{2}{*}{$\begin{array}{l}\text { Total } \\
\\
\mathrm{CO}_{2} \text {-eq } \\
(\mathrm{Gg})\end{array}$} \\
\hline & & $\begin{array}{l}\mathrm{CH}_{4} \\
(\mathrm{Gg})\end{array}$ & $\begin{array}{l}\mathrm{N}_{2} \mathrm{O} \\
(\mathrm{Gg})\end{array}$ & & $\begin{array}{l}\mathrm{CH}_{4} \\
(\mathrm{Mg})\end{array}$ & $\begin{array}{l}\mathrm{N}_{2} \mathrm{O} \\
(\mathrm{Mg})\end{array}$ & \\
\hline Lower Silesian & 8.27 & 3.13 & 0.23 & 4.37 & 45.20 & 0.0521 & 1656.46 \\
\hline Kuyavian-Pomeranian & 33.88 & 14.36 & 1.10 & 5.03 & 54.34 & 0.0686 & 3035.13 \\
\hline Lublin & 30.11 & 9.83 & 0.84 & 3.85 & 64.15 & 0.112 & 2396.62 \\
\hline Lubusz & 5.19 & 2.11 & 0.15 & 1.68 & 13.03 & 0.0112 & 728.29 \\
\hline Łódż & 34.92 & 12.55 & 1.03 & 3.85 & 48.49 & 0.0785 & 2641.86 \\
\hline Lesser Poland & 16.28 & 4.43 & 0.41 & 1.40 & 13.66 & 0.0253 & 1058.58 \\
\hline Masovian & 80.71 & 19.22 & 1.98 & 6.40 & 95.07 & 0.161 & 4999.51 \\
\hline Opole & 9.09 & 4.67 & 0.32 & 1.03 & 30.53 & 0.0314 & 749.05 \\
\hline Subcarpathian & 10.10 & 3.50 & 0.28 & 1.02 & 12.34 & 0.0205 & 729.21 \\
\hline Podlaskie & 66.27 & 11.15 & 1.48 & 2.51 & 22.23 & 0.0206 & 3126.70 \\
\hline Pomeranian & 14.53 & 6.35 & 0.46 & 3.82 & 26.14 & 0.0297 & 1795.85 \\
\hline Silesian & 9.51 & 3.62 & 0.27 & 1.20 & 11.44 & 0.0125 & 763.65 \\
\hline Świętokrzyskie & 13.61 & 4.13 & 0.36 & 0.84 & 23.35 & 0.0446 & 802.19 \\
\hline Warmian-Masurian & 32.98 & 7.97 & 0.82 & 2.12 & 26.12 & 0.0226 & 1902.07 \\
\hline Greater Poland & 60.96 & 30.62 & 2.14 & 5.09 & 79.60 & 0.0969 & 4444.49 \\
\hline West Pomeranian & 8.40 & 7.35 & 0.42 & 2.32 & 37.45 & 0.0356 & 1211.97 \\
\hline Poland & 434.81 & 145.01 & 12.29 & 46.53 & 603.14 & 0.823 & $32,141.63$ \\
\hline
\end{tabular}

province, representing approximately $15.6 \%$ of total emissions in Poland; the lowest emissions occur in the Lubuskie province.

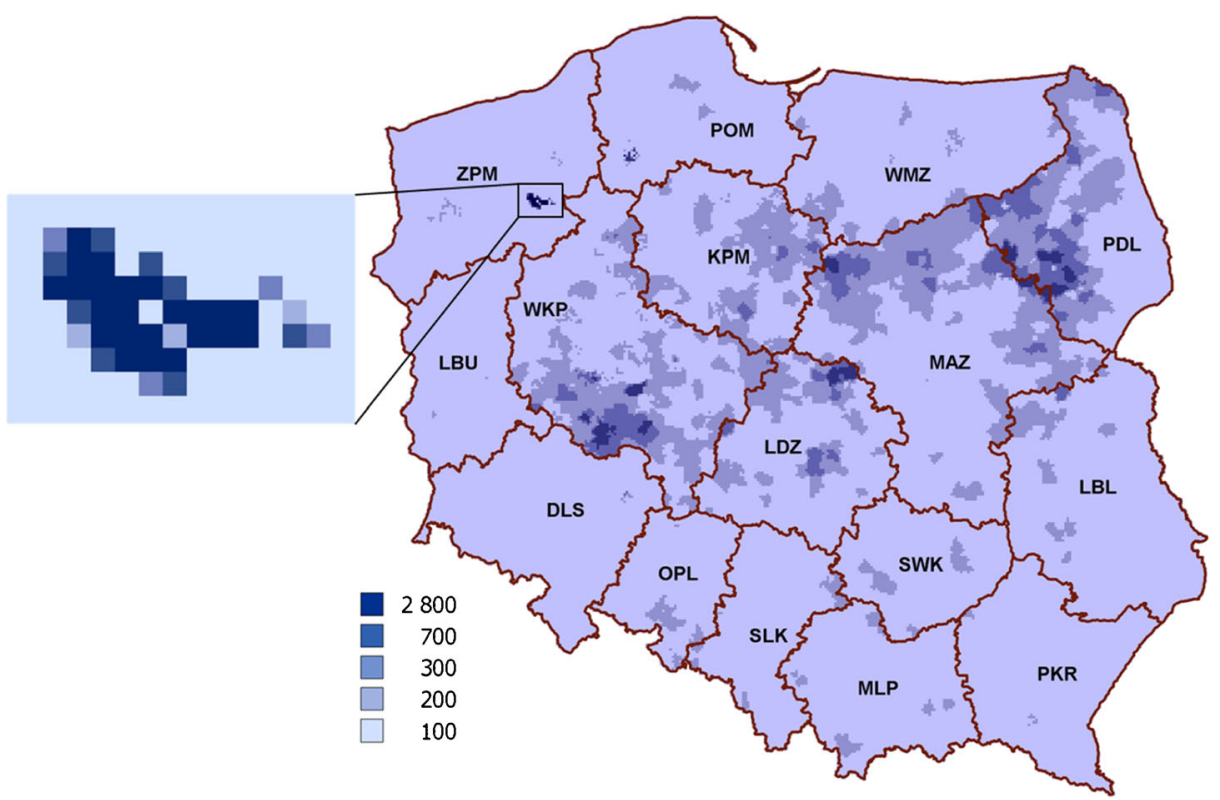

Fig. 5 Specific total GHG emissions in the livestock sector in Poland and the rural municipality Wierzchowo, with the highest emissions (grid $2 \times 2 \mathrm{~km} ; \mathrm{Mg} /$ cell/year, $\mathrm{CO}_{2}$-equivalent, 2010) 


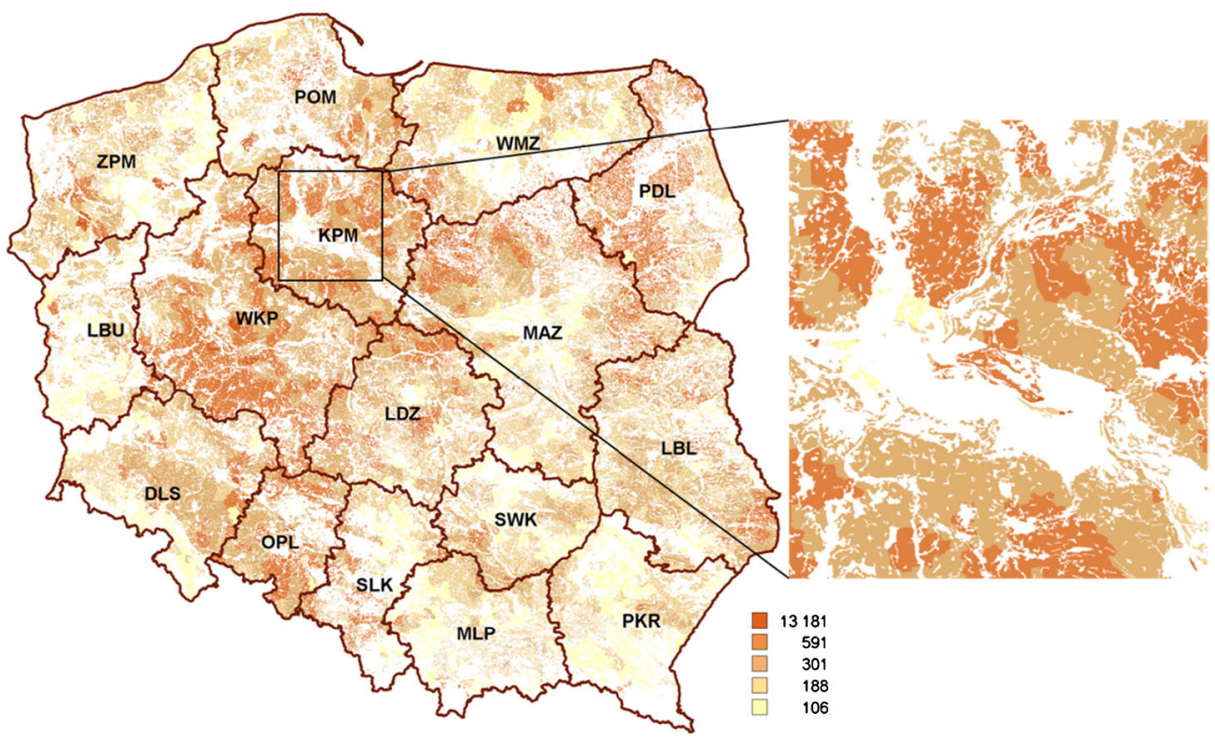

Fig. 6 Specific $\mathrm{N}_{2} \mathrm{O}$ emissions from IPCC '4D1.Direct Soil Emission' category in Poland (at the level of arable lands as areal emission sources, $\mathrm{kg} / \mathrm{km}^{2} /$ year, 2010)

Comparison with NIR data The calculated emissions were then aggregated to the whole territory of Poland and compared with the Polish annual national inventory report on GHG emissions for 2010 (NIR 2012). Table 2 contains comparison of the inventories compiled in this study with those published by NIR. The inventories for $\mathrm{CH}_{4}$ are quite close to each other. Those for $\mathrm{N}_{2} \mathrm{O}$, known for high uncertainty, differ more. But all of them are well within the uncertainty range calculated in the next section. In the spatial inventory, we used activity data

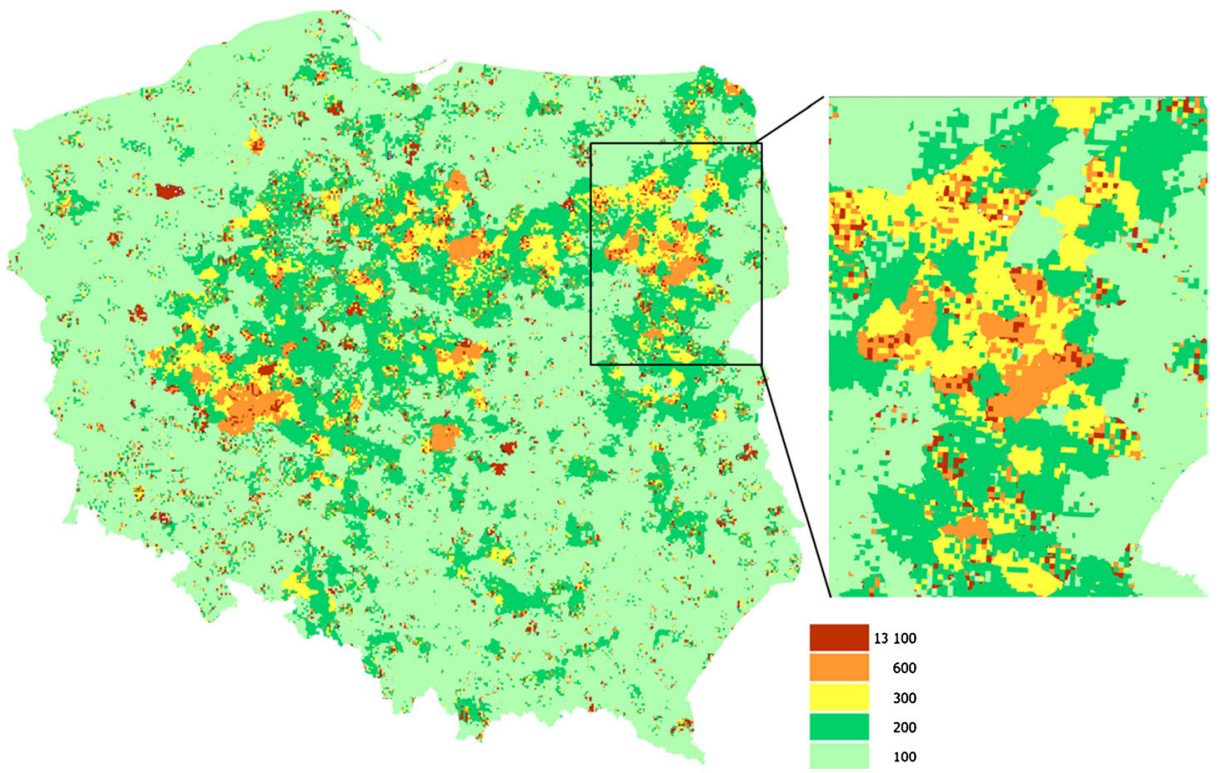

Fig. 7 Specific total $\mathrm{N}_{2} \mathrm{O}$ emissions in the agricultural sector in Poland (grid $2 \times 2 \mathrm{~km}, \mathrm{~kg} \mathrm{~N} \mathrm{~N}_{2} \mathrm{O} / \mathrm{km}^{2} /$ year, 2010) 


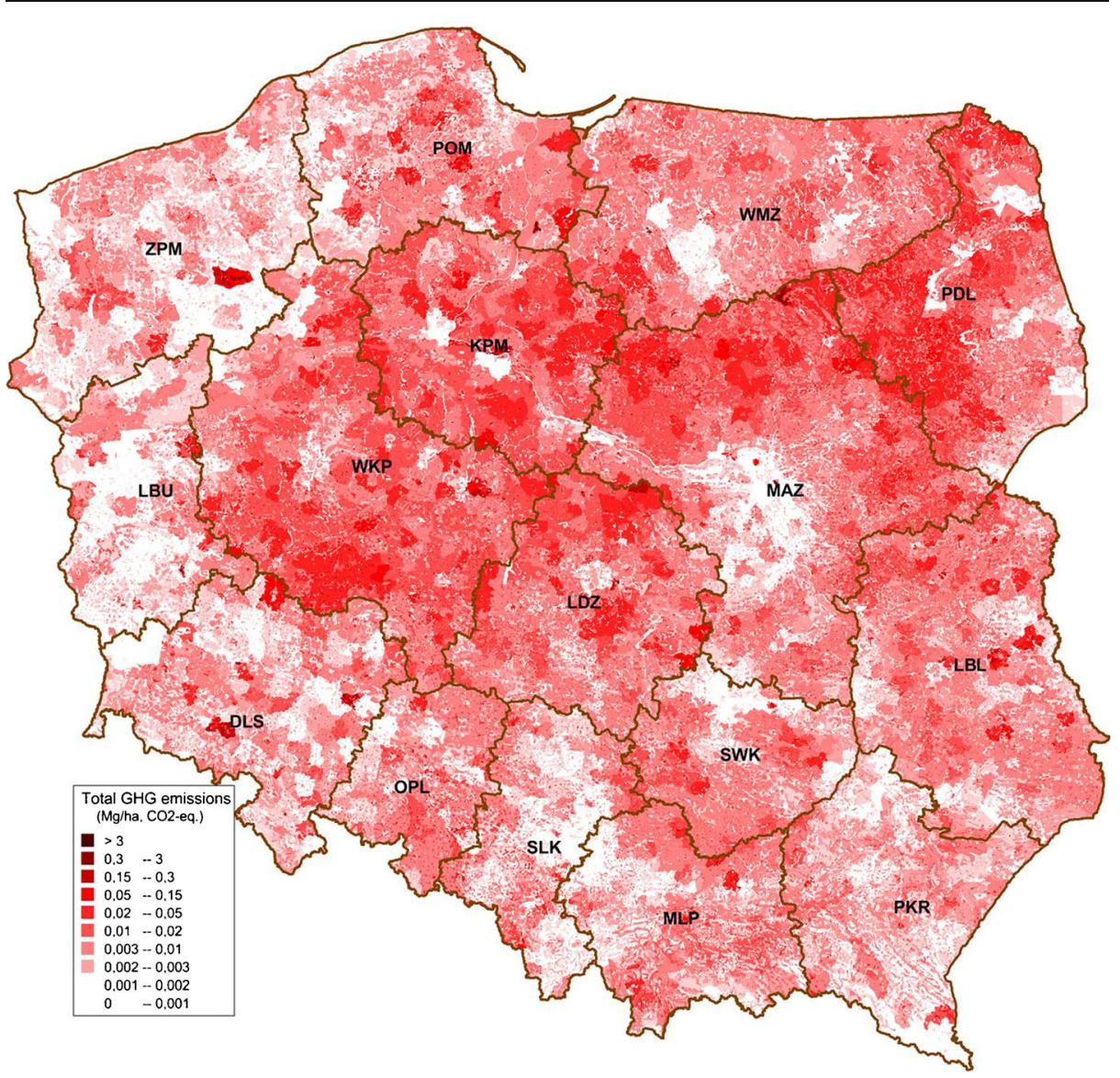

Fig. 8 Specific total GHG emissions in the agricultural sector in Poland (at the level of emission sources: arable lands, settlements, $\mathrm{Mg} \mathrm{CO}_{2}$-equivalent/ha/year, 2010)

and emission parameters at the level of municipalities, which provides more accurate data than those obtained in the national inventory, where average values are used. In general, our inventories provide lower values than those compiled by NIR, particularly for the $\mathrm{N}_{2} \mathrm{O}$ emissions. When converted to $\mathrm{CO}_{2}$-eq emissions using global warming potentials (IPCC 2007), the total for all emissions in our calculations is $32,026.8 \mathrm{Gg} \mathrm{CO}_{2}$-eq versus $36,065.5 \mathrm{Gg} \mathrm{CO}_{2}$-eq given by $\mathrm{NIR}$, so the relative difference equals $11.2 \%$. This is in surprisingly good agreement with $12 \%$ reduction of $\mathrm{CO}_{2}$ emission estimate obtained by revision of local activity data and emission coefficients, although in a different category of fossil fuel combustion and cement production, and distant country of China (Liu et al. 2015).

Table 2 Comparison of partial inventories of this study with NIR data

\begin{tabular}{lccc}
\hline & This study $(\mathrm{Gg})$ & NIR $(\mathrm{Gg})$ & Relative difference $(\%)$ \\
\hline Enteric fermentation, $\mathrm{CH}_{4}$ & 434.81 & 439.16 & 0.99 \\
Manure management, $\mathrm{CH}_{4}$ & 145.01 & 143.91 & 0.76 \\
Manure management, $\mathrm{N}_{2} \mathrm{O}$ & 12.28 & 16.81 & 26.9 \\
Agricultural soils, $\mathrm{N}_{2} \mathrm{O}$ & 46.55 & 55.30 & 15.8 \\
\hline
\end{tabular}




\subsection{Uncertainty analysis}

Uncertainty of GHG emissions represents a lack of knowledge about the actual value of emissions, for a certain area. The total uncertainty of the inventory is calculated using uncertainties of all input parameters using the statistical tools specified in the IPCC (2006) methodology. For this, uncertainty ranges for emission coefficients, statistical data, and other parameters of the inventory process are needed (IPCC 2001).

Uncertainty estimates of total emissions at the country level are important in analysis of the reduction of GHG emissions. The uncertainties are not constant and depend on the two main factors 'knowledge increase' about GHG emission/absorption processes and 'structural changes' in GHG emissions (Jonas et al. 2018). Therefore, increasing knowledge on uncertainty and on reasons for its change is important for the reduction of uncertainties in national GHG inventories (Boychuk and Bun 2014; Jarnicka and Nahorski 2018).

Input data for spatial inventory are not exactly known but can be simulated as random variables with known (estimated or assumed) distributions. For example, the livestock population (activity data) and the specific animal species' GHG emission factors can be modelled as random variables. This allows for modelling GHG emission uncertainty using the Monte Carlo method.

We analysed emission uncertainties in the agricultural sector at the level of provinces, focussing on enteric fermentation of farm animals (cows, nondairy cattle, sheep, goats, horses, and pigs). The uncertainty of statistical data on the animal livestock depends mainly on the completeness and reliability of the national census methods including different accounting rules for agricultural animals that live shorter than 1 year, such as pigs. Another source of uncertainty is uncertain data in the formulas for calculating the methane emission factor.

In the implemented mathematical models of GHG emission evaluation, the uncertainty range of the statistical data used for animal calculation is of $\pm 5 \%$ (normal distribution, $95 \%$ confidence interval). For modelling GHG emissions in the category 'Enteric Fermentation' by the Monte Carlo method, the methane emission factor for agricultural animals (IPCC 2001) and appropriate uncertainty ranges $( \pm 50 \%$, normal distribution, $95 \%$ confidence interval $)$ were used. With this data, the absolute uncertainties, i.e. half of $95 \%$ confidential interval, were calculated for Polish provinces using the Monte Carlo method for the statistical data from 2010 (Fig. 9). The highest absolute uncertainties were found for the Mazowian province followed by the Podlaskie province and by the Greater Poland province. The smallest absolute uncertainties are in the Lubusz province. However, the relative uncertainties were similar across provinces and close to $50 \%$.

\section{Discussion}

In this study, spatial analysis of the main GHG emission processes in the agricultural sector in Poland is performed, in particular, from animal enteric fermentation, manure management, agricultural soils, and burning of agricultural residues. For this, we consider rural settlements, arable lands, and pastures as emission sources. For each emission category, we build mathematical models that take into consideration activity data and emission factors as the input data. These data were basically acquired from the lowest possible level of municipalities. Some 


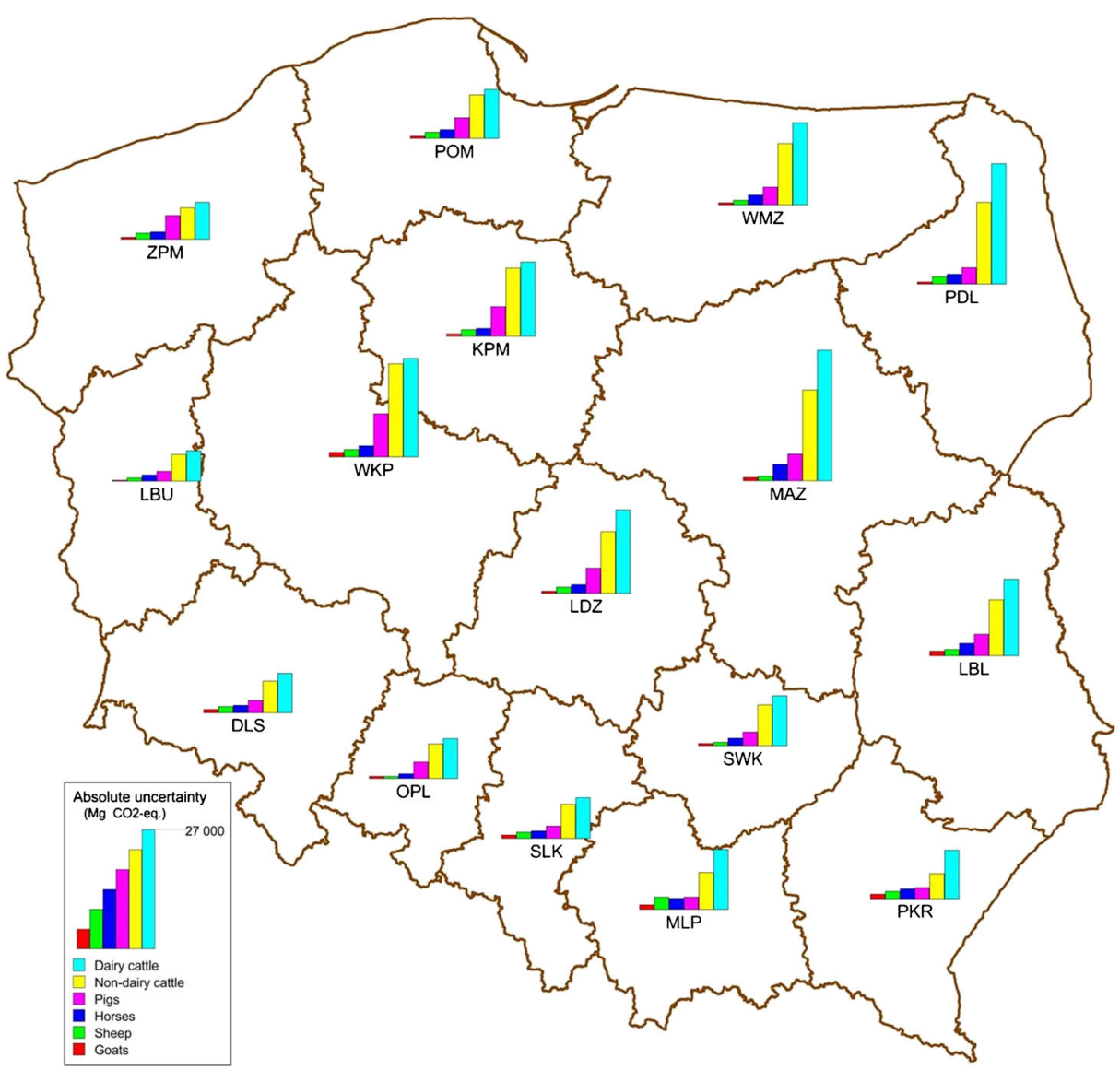

Fig. 9 Absolute uncertainties of methane emission from enteric fermentation of livestock in provinces of Poland (calculated as $1 / 2$ of $95 \%$ confidential interval, $\mathrm{Mg} \mathrm{CO}_{2}$-equivalent, square root scale, 2010)

statistical data on livestock numbers were, however, available only at the district level. To disaggregate them to the municipality level, we used a novel conditional autoregressive method, following the basic model presented by Horabik and Nahorski (2014). The municipality level activity data were further disaggregated to the elementary areal emission sources using as proxy the land cover and population density data that allowed us to build a georeferenced database of activity data and emission factors and compile high-resolution spatial inventory of GHG in the agriculture sector.

The results of this study indicate that the highest specific total GHG emissions in the animal sector in Poland, calculated from the $2 \mathrm{~km} \times 2 \mathrm{~km}$ cell level, occurred in the central and northeastern parts of the country. The highest specific emission, reaching $700 \mathrm{Mg} \mathrm{km}^{-2}$ year ${ }^{-1}$ of $\mathrm{CO}_{2}$-equivalent in 2010, occurred in the municipality of Wierzchowo in the West Pomeranian province, where large pig farms are located. An analysis of statistical information on livestock numbers in Poland in 2010 showed that in this municipality, the number of pigs exceeded 800,000 (CSOP 2010). This case and many others show that territorial emission distribution in the animal subsector is highly nonuniform. Therefore, spatial analysis of GHG 
emissions provides more accurate local data and is a helpful tool in taking effective policy measures to mitigate emissions.

The highest average specific emission, by which we mean specific emission calculated from the province level data, of $\mathrm{CH}_{4}$ for the animal sector is in the northeast of Poland, in Podlaskie province $\left(3.85 \mathrm{Mg}_{\mathrm{CH} 4} / \mathrm{km}^{2}\right)$, and the lowest in the west provinces near Germany border, namely Lubuskie $\left(0.52 \mathrm{Mg}_{\mathrm{CH} 4} / \mathrm{km}^{2}\right)$, Lower Silesian, and West Pomeranian provinces. In sparsely populated Podlaskie province, the per capita emission of methane in the animal sector is $65 \mathrm{~kg}$, while in densely populated industrial Silesian province only $2.8 \mathrm{~kg}$. In all provinces, emission of methane from dairy cattle enteric fermentation prevails and exceeds $50 \%$.

The highest specific $\mathrm{N}_{2} \mathrm{O}$ emissions from manure management occurred in some areas of the Kuyavian-Pomeranian province and reached average $13.18 \mathrm{Mg} \mathrm{km}^{-2}$ year ${ }^{-1}$ in $\mathrm{CO}_{2^{-}}$ equivalent. In this province, there is also the highest average specific direct emissions of nitrous oxide from soils $\left(82.9 \mathrm{Mg} \mathrm{km}^{-2}\right.$ year $^{-1}$ in $\mathrm{CO}_{2}$-eq), while the lowest is in forested Subcarpathian province (17.0 $\mathrm{Mg} \mathrm{km}^{-2}$ year $^{-1}$ in $\mathrm{CO}_{2}$-eq).

The average specific emission of total GHG in the agriculture sector calculated from the whole Poland spatial inventory data is equal to $102.5 \mathrm{Mg} \mathrm{km}^{-2}$ year $^{-1}$ in $\mathrm{CO}_{2}$-eq, but its distribution is highly spatially nonhomogeneous, from $169.6 \mathrm{Mg} \mathrm{km}^{-2}$ year ${ }^{-1}$ in $\mathrm{CO}_{2}$-eq in the Kuyavian-Pomeranian province with intensive agriculture and animal breeding to $41.0 \mathrm{Mg} \mathrm{km}^{-2}$ year $^{-1}$ in Subcarpathian province. The highest per capita emission is in Podlaskie province $\left(2.62 \mathrm{Mg}\right.$ year. ${ }^{-1}$ in $\mathrm{CO}_{2}$-eq), and smallest in Silesian province $\left(0.16 \mathrm{Mg}\right.$ year $\left.^{-1}\right)$, with country average $0.84 \mathrm{Mg}$ year $^{-1}$.

In all provinces, the highest absolute uncertainties were found for methane emission from enteric fermentation of dairy and nondairy cattle (the largest absolute uncertainties of emissions are in Masovian province: 26.6 and $12.7 \mathrm{Mg}$ year $^{-1}$ in $\mathrm{CO}_{2}$-eq, respectively). The absolute uncertainties for methane emission from enteric fermentation of pigs are smaller, followed by uncertainties of methane emission from enteric fermentation of horses and sheep. However, the relative emission uncertainties were fairly uniform in the provinces and close to $\pm 50 \%$ for all methane emissions from enteric fermentation. These uncertainties are greater than estimated, e.g. by Zhu et al. (2016), who estimated the methane emission uncertainty for EU-27 to be 16-19\%, but our results are for small territories, so less statistical averaging occurs.

\section{Conclusions}

The basic meaning of this study is in presenting a method of spatially resolved inventory of GHG emissions from the agricultural activity. These kinds of emissions are highly uneven in space, as documented above, both because of very differentiated spatially activity and of differentiated emission coefficients. This is connected with different soil, water availability, and meteorological conditions, as well as with agrotechnical practices that are much different in Polish regions, to big extent as a result of their different historical development. Highly space-dependent conditions are, however, quite typical factors influencing agricultural production in many regions of the world.

Spatial inventory allows for spatially specific use of emission coefficients that improves inventory accuracy as opposed to using average coefficients for big territories in a country level inventory. Preparation of a spatial inventory requires, however, 
disaggregation of activity data that are usually acquired from statistical reports for different administrative units. To minimise as much as possible uncertainty introduced by disaggregation, we use as low level of statistical data as only known. Moreover, for data which are known only on higher level, we use more accurate disaggregation method that takes into account spatial correlation of emissions. It is perhaps worth to add that statistical data are usually gathered with much better spatial resolution than those published by statistical offices. This gives room for further improvement of the final accuracy of spatial inventory.

Taking into account high uncertainty of the GHG emissions from the agricultural activity, more accurate inventory can help in better constraining atmospheric concentrations of GHG connected with emission fluxes. Apart of possibly higher accuracy of the spatial inventory itself, it provides unique possibility of giving input data to atmospheric dispersion models that enable confrontation of predicted increment in local atmospheric concentration with the real one. Using inverse modelling, it is in principle possible to further improve the accuracy of emissions; see Berdanier and Conant (2012), who reduced this way uncertainty of $\mathrm{N}_{2} \mathrm{O}$ emissions in world regions up to $65 \%$.

In comparison to the approaches of other studies, like Gerber et al. (2016), Leip et al. (2011), or Yao et al. (2006), our approach improves considerably the spatial resolution of GHG spatial inventory, which is possible by a novel and more detailed modelling and processing of the source (elementary object) emissions. Additional improvement of accuracy is obtained due to an applied statistical disaggregation method for activity data, developed by the authors, that takes into account the spatial autocorrelation of the emissions.

The obtained results on uncertainty analysis of methane emissions from enteric fermentation by animal species in the Polish regions show relatively high uncertainties of $\pm 50 \%$. This considerably impacts the uncertainty of the total regional or national emissions from all categories of anthropogenic activities. The uncertainty assessments at the level of elementary objects are hampered by lack of knowledge about uncertainty of some disaggregation parameters from the municipality to the elementary object/grid levels.

The basic idea of the method presented in this study consists in analysis of emissions from possibly homogenous elementary areal sources. This elementary emission sources are modelled in vector maps as polygons. It gives possibility to keep information on the administrative localization together with the emission sources that finally allows us to aggregate the results to the levels of municipalities, districts, or provinces without loss of accuracy. This paper presents implementation of this approach for high-resolution spatial analysis of GHG emission in the agricultural sector of Poland. It can be, however, used for any other countries or regions, taking into consideration their specificity of gathering statistical data on the lowest administrative levels and knowledge of the corresponding emission factors.

Identifying agricultural territories or administrative regions that have the greatest influence on overall emissions from agricultural activity opens new opportunities for improving the inventory process by investments in solutions to decrease the uncertainty in the input parameters (statistical data and emission coefficients). The most important is reduction of the emission coefficient uncertainties that play a key role in assessing uncertainty of the total emissions in the agriculture sector. Better estimates of the total uncertainty of regional or national emissions for all categories of anthropogenic activities would provide the authorities with data useful in reporting GHG emissions.

Spatial inventory of GHG emissions from agriculture is highly helpful in supporting local mitigation strategies, to find an optimal solution to satisfy usually contradictory goals of 
environmental protection on one side, and usage of agriculture potential for intensification and technological advancement on the other. However, as argued by Burney et al. (2010), the net effect of agricultural intensification for higher crop yields avoids emission of carbon. This opens a possibility to a win-win solution of higher productivity and smaller net emission, in which local adaptation policies add to global reduction of the atmospheric carbon.

Acknowledgements The study was partly conducted within the European Union FP7 Marie Curie Actions IRSES project No. 247645, acronym GESAPU.

\section{Appendix}

\section{The disaggregation framework: the basic conditional autocorrelation model}

As explanatory variables, we used population density (denoted $x_{1}$ ) and land use information (Corine Land Cover map (EEA 2006)). For each rural municipality, we calculated the area of the agricultural classes, which may be related to livestock farming. Three Corine classes were considered:

- $\quad$ Arable land, denoted $x_{2}$;

- Pastures, denoted $x_{3}$;

- Heterogeneous agricultural areas, denoted $x_{4}$

First, the model is specified on a level of fine grid. Let $Y_{i}$ denote a random variable associated with an unknown value of interest $y_{i}$ defined at each cell $i$ for $i=1, \ldots, n$ of a fine grid ( $n$ denotes the overall number of cells in a fine grid). The random variables $Y_{i}$ are assumed to follow the Gaussian distribution with the mean $\mu_{i}$ and variance $\sigma_{Y}^{2}$

$$
Y_{i} \mid \mu_{i} \sim \operatorname{Gau}\left(\mu_{i}, \sigma_{Y}^{2}\right)
$$

Given the values $\mu_{i}$ and $\sigma_{Y}^{2}$, the random variables $Y_{i}$ are assumed independent. The mean $\boldsymbol{\mu}=\left\{\mu_{i}\right\}_{i=1}^{n}$ represents the true process underlying emissions, and the (unknown) observations are related to this process through a measurement error with the variance $\sigma_{Y}^{2}$. The approach to modelling $\mu_{i}$ expresses an assumption that available covariates explain part of the spatial pattern and that the remaining part is captured through a spatial dependence. The conditional autocorrelation (CAR) scheme follows an assumption of similar random effects in adjacent cells, and it is given through the specification of full conditional distribution functions of $\mu_{i}$ for $i=1, \ldots, n$

$$
\mu_{i} \mid \boldsymbol{\mu}_{-i} \sim G a u\left(\boldsymbol{x}_{i}^{T} \boldsymbol{\beta}+\rho \cdot \sum_{\substack{j \neq i \\ j \neq i}}^{n} \frac{w_{i j}}{w_{i+}}\left(\mu_{j}-\boldsymbol{x}_{j}^{T} \boldsymbol{\beta}\right), \frac{\tau^{2}}{w_{i+}}\right)
$$

where $\mu_{i}$ denotes all elements in $\boldsymbol{\mu} ; w_{i j}$ are the adjacency weights ( $w_{i j}=1$ if $j$ is a neighbour of $i$ and 0 otherwise, also $\left.w_{i i}=0\right) ; w_{i+}=\sum_{j} w_{i j}$ is the number of neighbours of an area $i ; \boldsymbol{x}_{i}^{T} \boldsymbol{\beta}$ is a regression component with proxy information available for area $i$ and a respective vector of 
Table 3 Maximum likelihood estimates of the spatial (CAR) and linear (LM) model parameters

\begin{tabular}{lllll}
\hline & \multicolumn{2}{l}{ CAR } & & \multicolumn{2}{l}{ LM } \\
\cline { 2 - 3 } \cline { 5 - 5 } & Estimate & Std. error & Estimate & Std. error \\
\hline$\beta_{0}$ & 8.525 & 0.1605 & -6.981 & 0.0389 \\
$\beta_{1}$ & 3.517 & 0.0148 & 1.932 & 0.0042 \\
$\beta_{2}$ & - & - & - & - \\
$\beta_{3}$ & 0.916 & 0.0034 & 1.786 & 0.0010 \\
$\beta_{4}$ & 3.912 & 0.0055 & 5.032 & 0.0013 \\
$\sigma_{Z}^{2}$ & 0.961 & 0.4052 & 1.506 & 0.1202 \\
$\tau^{2}$ & 1.683 & 0.1569 & - & - \\
$\rho$ & 0.9889 & $2.62 \mathrm{e}-06$ & - & - \\
\hline
\end{tabular}

regression coefficients; $\tau^{2}$ is a variance parameter. Thus, the mean of the conditional distribution $\mu_{i} \mid \boldsymbol{\mu}_{-i}$ consists of the regression part and the second summand, which is proportional to the average values of remainders $\mu_{j}-\boldsymbol{x}_{i}^{T} \boldsymbol{\beta}$ for neighbouring sites (i.e. when $w_{i j}=1$ ). The proportion is calibrated with the parameter $\rho$, reflecting strength of a spatial association. Furthermore, the variance of the conditional distribution $\mu_{i} \mid \boldsymbol{\mu}_{-i}$ is inversely proportional to the number of neighbours $w_{i+}$.

The joint distribution of the process $\boldsymbol{\mu}$ is the following (for the derivation see Kaiser et al. (2002))

$$
\boldsymbol{\mu} \sim \operatorname{Gau}\left(\boldsymbol{X} \boldsymbol{\beta}, \tau^{2}(\boldsymbol{D}-\rho \boldsymbol{W})^{-1}\right)
$$

where $\boldsymbol{D}$ is an $n \times n$ diagonal matrix with $w_{i+}$ on the diagonal; and $\boldsymbol{W}$ is an $n \times n$ matrix with adjacency weights $w_{i j}$. Equivalently, we can write (3) as

$$
\boldsymbol{\mu}=\boldsymbol{X} \boldsymbol{\beta}+\varepsilon, \varepsilon \sim \operatorname{Gau}_{n}(\mathbf{0}, \boldsymbol{\Omega}),
$$

with $\boldsymbol{\Omega}=\tau^{2}(\boldsymbol{D}-\rho \boldsymbol{W})^{-1}$.

The model for a coarse grid of (aggregated) observed data is obtained by multiplication of (4) with the $N \times n$ aggregation matrix $\boldsymbol{C}$, where $N$ is the number of observations in the coarse grid

$$
\boldsymbol{C} \boldsymbol{\mu}=\boldsymbol{C X} \boldsymbol{\beta}+\boldsymbol{C} \varepsilon, C \varepsilon \sim \operatorname{Gau}_{n}\left(\mathbf{0}, \boldsymbol{C} \boldsymbol{\Omega} \boldsymbol{C}^{T}\right),
$$

The aggregation matrix $C$ consists of 0's and 1's, indicating which cells must be aligned together. The random variable $\boldsymbol{\lambda}=\boldsymbol{C} \boldsymbol{\mu}$ is treated as the mean process for variables $\boldsymbol{Z}=\left\{Z_{i}\right\}_{i=1}^{N}$ associated with observations $\boldsymbol{z}=\left\{z_{i}\right\}_{i=1}^{N}$ in the coarse grid

Table 4 Analysis of residuals $\left(d_{i}=y_{i}-y_{i}{ }^{*}\right)$ of the spatial (CAR), linear (LM), and naïve (NV) models

\begin{tabular}{llllr}
\hline & mse & $\min \left(d_{i}\right)$ & $\max \left(d_{i}\right)$ & $r$ \\
\hline CAR & 3069.4 & -275 & 469 & 0.784 \\
LM & 5641.2 & -357 & 522 & 0.555 \\
NV & 3374.4 & -475 & 403 & 0.766 \\
\hline
\end{tabular}




$$
\boldsymbol{Z} \mid \boldsymbol{\lambda} \sim \operatorname{Gau}_{N}\left(\boldsymbol{\lambda}, \sigma_{Z}^{2} \boldsymbol{I}_{N}\right)
$$

Also at this level, the underlying process $\boldsymbol{\lambda}$ is related to $\boldsymbol{Z}$ through a measurement error with variance $\sigma_{Z}^{2}$.

Model parameters $\boldsymbol{\beta}, \quad \sigma_{Z}^{2}, \quad \tau^{2}$ and $\rho$ are estimated with the maximum likelihood method based on the joint unconditional distribution of observed random variables $Z$ :

$$
\boldsymbol{Z} \sim \operatorname{Gau}_{N}\left(\boldsymbol{C X} \boldsymbol{\beta}, \sigma_{Z}^{2} \boldsymbol{I}_{N}+\boldsymbol{C} \boldsymbol{\Omega} \boldsymbol{C}^{T}\right)
$$

The log likelihood function associated with (5) is formulated, and the analytical derivation is limited to the regression coefficients $\boldsymbol{\beta}$; further maximisation of the profile log likelihood is performed numerically.

As to the prediction of missing values in a fine grid, the underlying mean process $\boldsymbol{\mu}$ is of our primary interest. The predictors optimal in terms of the mean squared error are given by the conditional expected value $E(\boldsymbol{\mu} \mid \boldsymbol{z})$. The joint distribution of $(\boldsymbol{\mu}, \boldsymbol{Z})$ is

$$
\left[\begin{array}{c}
\boldsymbol{\mu} \\
\boldsymbol{Z}
\end{array}\right] \sim \operatorname{Gau}_{n+N}\left(\left[\begin{array}{c}
\boldsymbol{X} \boldsymbol{\beta} \\
\boldsymbol{C} \boldsymbol{X} \boldsymbol{\beta}
\end{array}\right],\left[\begin{array}{cc}
\boldsymbol{\Omega} & \boldsymbol{\Omega} \boldsymbol{C}^{T} \\
\boldsymbol{\Omega} \boldsymbol{C} & \sigma_{\boldsymbol{Z}}^{2} \boldsymbol{I}_{N}+\boldsymbol{C} \boldsymbol{\Omega} \boldsymbol{C}^{T}
\end{array}\right]\right)
$$

The distribution (6) yields both the predictor $E(\hat{\boldsymbol{\mu}} \mid \boldsymbol{z})$ and its error $\operatorname{Var}(\boldsymbol{\mu} \mid \boldsymbol{z})$

$$
\begin{gathered}
E(\hat{\boldsymbol{\mu}} \mid \boldsymbol{z})=\boldsymbol{X} \hat{\boldsymbol{\beta}}+\hat{\boldsymbol{\Omega}} \boldsymbol{C}^{T}\left(\hat{\sigma}_{Z}^{z} \boldsymbol{I}_{N}+\boldsymbol{C} \hat{\boldsymbol{\Omega}} \boldsymbol{C}^{\mathrm{T}}\right)^{-1}[\boldsymbol{z}-\boldsymbol{C X} \hat{\boldsymbol{\beta}}], \\
\operatorname{Var} \hat{\boldsymbol{\mu}} \mid \boldsymbol{z})=\hat{\boldsymbol{\Omega}}-\hat{\boldsymbol{\Omega}} \boldsymbol{C}^{T}\left(\hat{\sigma}_{Z}^{z} \boldsymbol{I}_{N}+\boldsymbol{C} \hat{\boldsymbol{\Omega}} \boldsymbol{C}^{\mathrm{T}}\right)^{-1} \boldsymbol{C} \hat{\boldsymbol{\Omega}} .
\end{gathered}
$$

The standard errors of parameter estimators are calculated with the Fisher information matrix based on the log likelihood function, see Horabik and Nahorski (2015).

Table 3 presents the estimation results (parameters with their standard errors) for the models with and without a spatial component, denoted CAR and LM (linear model), respectively. Note that in this setting, the variable $\beta_{2}$ (land use class arable land) turned out to be statistically insignificant. Introduction of the spatial CAR structure increased the standard error of estimated parameters, as compared with the LM model.

The goodness of fit is described in Table 4, which contains the results of the analysis of residuals $\left(d_{i}=y_{i}-y_{i}{ }^{*}\right.$, where $y_{i}{ }^{*}$ are the predicted values) for the considered models. We report the mean squared error mse, the minimum and maximum values of $d_{i}$ and the sample correlation coefficient $r$ between the predicted and observed values.

Open Access This article is distributed under the terms of the Creative Commons Attribution 4.0 International License (http://creativecommons.org/licenses/by/4.0/), which permits unrestricted use, distribution, and reproduction in any medium, provided you give appropriate credit to the original author(s) and the source, provide a link to the Creative Commons license, and indicate if changes were made. 


\section{References}

AGHGS (2017) Agriculture-greenhouse gas emission statistics, Eurostat Statistics Explained. Available at: http://ec.europa.eu/eurostat/statistics-explained/index.php/Agriculture_-_greenhouse_gas_emission statistics. Cited 16 Aug 2017

BDL (2017) Bank Danych Lokalnych (Local Data Bank), GUS, Warsaw, Poland Available at: http://statgovpl/bdl Cited 10 Aug 2017

Beach RH, Creason J, Ohrel SB, Ragnauth S, Ogle S, Li C, Ingraham P, Salas W (2016) Global mitigation potential and costs of reducing agricultural non- $\mathrm{CO} 2$ greenhouse gas emissions through 2030. J Integr Environ Sci 12(sup1):87-105. https://doi.org/10.1080/1943815X.2015.1110183

Berdanier AB, Conant R (2012) Regionally differentiated estimates of cropland $\mathrm{N}_{2} \mathrm{O}$ emissions reduce uncertainty in global calculations. Glob Chang Biol 18(3):928-935. https://doi.org/10.1111/j.13652486.2011.02554.x

Boychuk K, Bun R (2014) Regional spatial inventories (cadastres) of GHG emissions in energy sector: accounting for uncertainty. Clim Chang 124(3):561-574. https://doi.org/10.1007/s10584-013-1040-9

Bun R, Gusti M, Kujii L, Tokar O, Tsybrivskyy Y, Bun A (2007) Spatial GHG inventory: analysis of uncertainty sources. A case study for Ukraine. Water Air Soil Poll Focus 7(4-5):483-494. https://doi.org/10.1007 /s11267-006-9116-4

Bun R, Nahorski Z, Horabik-Pyzel J, Danylo O, See L, Charkovska N, Topylko P, Halushchak M, Lesiv M, Valakh M, Kinakh V (2018) Development of a high resolution spatial inventory of GHG emissions for Poland from stationary and mobile sources (this issue)

Burney JA, Davis SJ, Lobell DB (2010) Greenhouse gas mitigation by agricultural intensification. Proc Natl Acad Sci U S A 107(26):12052-12057. https://doi.org/10.1073/pnas.0914216107

Butterbach-Bahl K, Baggs EM, Dannenmann M, Kiese R, Zechmeister-Boltenstern S (2013) Nitrous oxide emissions from soils: how well do we understand the processes and their controls? Philos Trans R Soc B 368(1621):20130122. https://doi.org/10.1098/rstb.2013.0122

Büttner G, Kosztra B, Maucha G, Pataki R (2012) Implementation and achievements of CLC2006, Institute of Geodesy, Cartography and Remote Sensing (FÖMI), 65 p

Caro D, Davis SJ, Bastianoni S, Caldeira K (2014) Global and regional trends in greenhouse gas emissions from livestock. Clim Chang 126(1-2):203-216. https://oi.org/10.1007/s10584-014-1197-x

Cook J, Oreskes N, Doran PT, Anderegg WRL, Verheggen B, Maibach E, Carlton JS, Lewandowsky S, Skuce AG, Green SA, Nuccitelli D, Jacobs P, Richardson M, Winkler B, Painting R, Rice K (2016) Consensus on consensus: a synthesis of consensus estimates on human-caused global warming. Environ Res Lett 11: 048002. https://doi.org/10.1088/1748-9326/11/4/048002

CSOP (2010) Central Statistical Office of Poland. Agricultural census 2010 by holdings headquater; Livestock (cattle, pigs, horses, poultry) Available at: http://wwwstatgovpl Cited 15 May 2017

EDGAR (2017) Emissions Database for Global Atmospheric Research (Joint Research Centre). Available at: http://edgarjrceceuropaeu/ Cited 20 November 2017

EEA (2006) European Environment Agency, Corine Land Cover 2006 Available at: http://wwweeaeuropaeu/data-and-maps/data Cited 15 Jul 2017

Fu C, Yu G (2010) Estimation and spatiotemporal analysis of methane emissions from agriculture in China. Environ Manag 46(4):618-632. https://doi.org/10.1007/s00267-010-9495-1

Gerber JS, Carlsson KM, Makowski D, Mueller ND, de Cortazar-Atauri IG, Havlík P, Herrero M, Launay M, O'Connell CS, Smith P, West P (2016) Spatially explicit estimates of $\mathrm{N}_{2} \mathrm{O}$ emissions from cropland suggest climate mitigation opportunities from improved fertilizer management. Glob Chang Biol 22(10):3383-3394. https://doi.org/10.1111/gcb.13341

Havlík P, Leclère D, Valin H, Herrero M, Schmid E, Soussana JF, Müller C, Obersteiner M (2015) Global climate change, food supply and livestock production systems: a bioeconomic analysis. In: Elbehri A (ed) Climate change and food systems: global assessments and implications for food security and trade. Food Agriculture Organization of the United Nations (FAO), Rome, pp 176-209

Herrero M, Wirsenius S, Henderson B, Rigolot C, Thornton P, Havlík P, de Boer I, Gerber PJ (2015) Livestock and the environment: what have we learned in the past decade? Annu Rev Environ Resour 40(1):177-202. https://doi.org/10.1146/annurev-environ-031113-093503

Horabik J, Nahorski Z (2010) A statistical model for spatial inventory data: a case study of $\mathrm{N}_{2} \mathrm{O}$ emissions in multicipalities of Southern Norway. Clim Chang 103:236-276. https://doi.org/10.1007/s10584-010-9913-7

Horabik J, Nahorski Z (2014) Improving resolution of a spatial air pollution inventory with a statistical inference approach. Clim Chang 124(3):575-589. https://doi.org/10.1007/s10584-013-1029-4

Horabik J, Nahorski Z (2015) The Cramér-Rao lower bound for the estimated parameters in a spatial disaggregation model for areal data. In: Filev D et al (eds) Intelligent Systems'2014. Advances in Intelligent Systems and Computing, vol 323. Springer, Cham, pp 661-668. https://doi.org/10.1007/978-3-319-11310-4_57 
IPCC (2001) Good practice guidance and uncertainty Management in National Greenhouse gas Inventories. Penman J, Kruger D, Galbally I et al. Available: http://wwwipcc-nggipigesorjp/public/gp/english/ Cited 30 Jun 2017

IPCC (2006) IPCC Guidelines for National Greenhouse Gas Inventories, prepared by the National Greenhouse Gas Inventories Programme, Eggleston HS, Buendia L, Miwa K, Ngara T, Tanabe K (eds). Available at: http://www.ipcc-nggip.iges.or.jp/public/2006gl/. Cited 02 Aug 2017

IPCC (2007) Climate change 2007: synthesis report. Contribution of Working Groups I, II and III to the Fourth Assessment Report of the Intergovernmental Panel on Climate Change, Core writing team, Pachauri, R.K. and Reisinger, A. (Eds.), IPCC, Geneva, Switzerland. http://www.ipcc.ch/publications_and_ data/publications_ipcc_fourth_assessment_report_synthesis_report.htm. Cited 18 Nov 2017

IPCC (2013) Climate change 2013: the physical science basis. Contribution of Working Group I to the Fifth Assessment Report of the Intergovernmental Panel on Climate Change [Stocker TF, Qin D, Plattner GK, Tignor M, Allen SK, Boschung J, Nauels A, Xia Y, Bex V, Midgley PM (eds.)]. Cambridge University Press, Cambridge, United Kingdom and New York, NY, USA. http:/www.ipcc.ch/report/ar5/wg2/. Cited 05 Sep 2017

IPCC (2014) Climate change 2014: impacts, adaptation, and vulnerability. Part A: Global and sectoral aspects. Contribution of Working Group II to the Fifth Assessment Report of the Intergovernmental Panel on Climate Change. Field CB, Barros VR, Dokken DJ, Mach KJ, Mastrandrea MD, Bilir TE, Chatterjee M, Ebi KL, Estrada YO, Genova RC, Girma B, Kissel ES, Levy AN, MacCracken S, Mastrandrea PR, White LL (eds). Cambridge University Press, Cambridge and New York. http:/www.ipcc.ch/report/ar5/wg2/. Cited 19 Sep 2017

Jarnicka J, Nahorski Z (2018) Estimation of means an a bivariate discrete-time process. In: KT Atanassov, J Kacprzyk, A Kałuszko, M Krawczak, J Owsiński, S Sotirov, E Sotirova, E Szmidt, S Zadrożny (eds) Uncertainty and imprecision in decision making and decision support: cross fertilization, new models and applications. Springer, Ser. Advances in Intelligent Systems and Computing, vol. 559, 3-11. https:/doi. org/10.1007/978-3-319-65545-1 1

Johnson JMF, Franzluebbers AJ, Weyers SL, Reicosky DC (2007) Agricultural opportunities to mitigate greenhouse gas emissions. Environ Pollut 150(1):107-124. https://doi.org/10.1016/j.envpol.2007.06.030

Jonas M, Żebrowski P, Jarnicka J (2018) The crux with reducing emissions in the long-term: The underestimated now versus the overestimated then. Mitig Adapt Strat Gl (this issue)

Kaiser MS, Daniels MJ, Furakawa K, Dixon P (2002) Analysis of particulate matter air pollution using Markov random field models of spatial dependence. Environmetrics 13(5-6):615-628. https://doi.org/10.1002/env.534

Kim T, Dall'erba S (2014) Spatio-temporal association of fossil fuel $\mathrm{CO}_{2}$ emissions from crop production across US counties. Agric Ecosyst Environ 183:69-77. https://doi.org/10.1016/j.agee.2013.10.019

Leip A, Busto M, Winiwarter W (2011) Developing spatially stratified $\mathrm{N}_{2} \mathrm{O}$ emission factors for Europe. Environ Pollut 159(1):3223-3232. https://doi.org/10.1016/j.envpol.2010.11.024

Lesk C, Rowhani P, Ramankutty N (2016) Influence of extreme weather disasters on global crop production. Nature 529(7584):84-87. https://doi.org/10.1038/nature16467

Liu Z, Guan D, Wei W, Davis SJ, Ciais P, Bai J, Peng S, Zhang Q, Hubacek K, Marland G, Andres RJ, CrawfordBrown D, Lin J, Zhao H, Hong C, Boden TA, Feng K, Peters GP, Xi F, Liu J, Li Y, Zhao Y, Zeng N, He K (2015) Reduced carbon emission estimates from fossil fuel combustion and cement production in China. Nature 524(7565):335-338. https://doi.org/10.1038/nature14677

NIR (2012) Poland's National Inventory Report 2012, KOBIZE, Warsaw, 358 p Available at: http://unfcccint/national reports Cited 10 Aug 2017

Ogle SM, Buendia L, Butterbach-Bahl K, Breidt FJ, Martman M, Yagi K, Nayamuth R, Spencer S, Wirth T, Smith P (2013) Advancing national greenhouse gas inventories for agriculture in developing countries: improving activity data, emission factors and software technology. Environ Res Lett 8(1):015030/1-015030/ 8. https://doi.org/10.1088/1748-9326/8/1/015030

PBI (2017) Poland: basic information. Available at: http://ammanmfagovpl/en/bilateral_relations/come_to poland/poland_basic_information/ Cited 15 Sep 2017

Smith P, Martino D, Cai Z, Gwary D, Janzen H, Kumar P, McCarl B, Ogle S, O’Mara F, Rice C, Scholes B, Sirotenko O, Howden M, McAllister T, Pan G, Romanenkov V, Schneider U, Towprayoon S, Wittenbach M, Smith J (2008) Greenhouse gas mitigation in agriculture. Philos Trans R Soc B 363(1492):789-813. https://doi.org/10.1098/rstb.2007.2184

Snyder CS, Bruulsema TW, Jensen TL, Fixen PE (2009) Review of greenhouse gas emissions from crop production systems and fertilizer management effects. Agric Ecosyst Environ 133(3-4):247-266. https://doi.org/10.1016/j.agee.2009.04.021

Soussana JF, Allard V, Pilegaard K, Ambus P, Amman C, Campbell C, Ceschia E, Clifton-Brown J, Czobel S, Dominigues R, Flechard C, Fuhrer J, Hensen A, Horvath L, Jones M, Kasper G, Martin C, Nagy Z, Neftel A, Raschi A, Baronti S, Rees RM, Skiba U, Stefani P, Manca G, Sutton M, Tuba Z, Valentini R (2007) Full accounting of the greenhouse gas $\left(\mathrm{CO}_{2}, \mathrm{~N}_{2} \mathrm{O}, \mathrm{CH}_{4}\right)$ budget of nine European grassland sites. Agric Ecosyst Environ 121(1-2):121-134. https://doi.org/10.1016/j.agee.2006.12.022 
Szwed M, Karg G, Pinskwar I, Radziejewski M, Graczyk D, Kędziora A, Kundzewicz ZW (2010) Climate change and its effect on agriculture, water resources and human health sectors in Poland. Nat Hazards Earth Syst Sci 10(8):1725-1737. https://doi.org/10.5194/nhess-10-1725-2010

Trombetti M, Pisoni E, Lavalle C (2017) Downscaling methodology to produce a high resolution gridded emission inventory to support local/city level air quality policies. JCR Technical Report, EUR 28428 EN. https://doi.org/10.2760/51058

Weiss F, Leip A (2012) Greenhouse gas emissions from the EU livestock sector: a life cycle assessment carried out with the CAPRI model. Agric Ecosyst Environ 149:124-134. https://doi.org/10.1016/j.agee.2011.12.015

Wollenberg E, Richards M, Smith P, Havlík P, Obersteiner M, Tubiello FN, Herold M, Gerber P, Carter S, Reisinger A, van Vuuren D, Dickie A, Neufeldt H, Sander BO, Wassmann R, Sommer R, Amonette JE, Falcucci A, Herrero M, Opio C, Roman-Cuesta R, Stehfest E, Westhoek H, Ortiz-Monasterio I, Sapkota T, Rufino MC, Thornton PK, Verchot L, West PC, Soussana JF, Baedeker T, Sadler M, Vermeulen S, Campbell $\mathrm{BM}$ (2016) Reducing emissions from agriculture to meet the $2^{\circ} \mathrm{C}$ target. Glob Chang Biol 22(12):38593864. https://doi.org/10.1111/gcb.13340

Yao H, Wen Z, Xunhua Z, Shenghui H, Yongqiang Y (2006) Estimates of methane emissions from Chinese rice paddies by linking a model do GIS database. Acta Ecol Sin 26(4):980-988. https://doi.org/10.1016/S18722032(06)60016-4

Young MT, Bechle MJ, Sampson PD, Szpiro AA, Marshall JD, Sheppard L, Kaufman JD (2016) Satellite-based $\mathrm{NO}_{2}$ and model validation in a national prediction model based on universal kriging and land-use regression. Environ Sci Technol 50(7):3686-3694. https://doi.org/10.1021/acs.est.5b05099

Zhang W, Zhang Q, Huang Y, Li TT, Bian JY, Han PF (2014) Uncertainties in estimating regional methane emissions from rice paddies due to data scarcity in the modelling approach. Geosci Model Dev 7(3):12111224. https://doi.org/10.5194/gmd-7-1211-2014

Zhu B, Kros J, Lesschen JP, Staritsky IG, de Vries W (2016) Assessment of uncertainties in greenhouse gas emission profiles of livestock sectors in Africa, Latin America and Europe. Reg Environ Chang 16(6):15711582. https://doi.org/10.1007/s10113-015-0896-9 